Earnings Disparities in the Czech Republic: Evidence of the Past Decade and Cross-National Comparison

$$
\text { By: Jiri Vecernik }
$$

Working Paper No. 373

May 2001 


\title{
Earnings disparities in the Czech Republic: evidence of the past decade and cross-national comparison
}

\author{
Jiri Vecernik \\ Institute of Sociology, Academy of Sciences, Jilska 1, 11000 Praha 1 \\ e-mail: vecernik@soc.cas.cz
}

\begin{abstract}
:
Wage and income surveys covering the period 1989-1999 are used to display changes in inequality of earnings and main factors of disparities. In the first part, increasing differences in the Czech Republic and the decreasing weight of demographic characteristics in wage structure are observed. In the second part, available evidence on cross-national comparison is gathered in order to demonstrate the increasing similarity of the Czech wage structure with that in Western countries. We document that the introduction of a market economy has led to an increase in earnings disparities more similar to those in the West; the "communist" demographic determination of earnings is being replaced to a great extent by "capitalist" market characteristics; and ownership disparities, instead of political privileges, have come to the fore. Thus, the overall earnings structure underwent systemic changes and approaches the Western pattern.
\end{abstract}

Keywords: earnings disparities, returns to education, gender gap, transition in the Czech Republic.

JEL Classification: J31. 


\section{Non-technical Summary}

Wage and income surveys are used to display changes in inequality of earnings and the main determinants of disparities in the Czech Republic. In the first part, the decade 1989-1999 is surveyed, and the increasing differences in earnings and decreasing weight of demographic characteristics in wage determination are observed. In the second part, available evidence for crossnational comparison is gathered, and the increasing similarity of the Czech wage structure with those found in Western countries is demonstrated.

Pre-1989 Czechoslovakia was characterized by a considerable equalization of wages and, within remaining disparities, by a predominance of the demographic features of individuals (gender and age) over their market characteristics (skills and occupation) in determination of earnings.

Alongside this, some industries (mining, metallurgy, heavy machinery) were favored, and selected categories of workers (top state and party bureaucracy, army and police officers) privileged. Behind the facade of an almost stable range and small overall disparities, demographic determinants (indicating the level of need) were even strengthened and so-called productive industries promoted, while the wage position of more highly educated people declined and the younger generations were disadvantaged in favor of older workers.

Since 1989, the transformation process has reversed all those tendencies and started to change the established earnings structure. The overall range of inequality in wages has increased, as have returns to education, while the gender gap has somewhat attenuated and the age profile of earnings has became considerably flatter. In the division according to industry, the former administrative "tariff grid" was replaced by market differences to a considerable, though not a complete degree. In the public sector, a new and simpler tariff grid has been applied which (again) favors experience above qualification. In most of the private sector, wages are negotiated between employers and trade unions. Lawyers, managers and experts in marketing and other special services to foreign firms already enjoy salaries comparable with their Western counterparts.

Despite a step-by-step adjustment of the earnings structure, the current system is still a mixture of previous features (as the large importance of gender division witnesses), transitory characteristics (displayed especially by disparities among ownership sectors) and a targeted system (which is at best documented by increasing returns to education). Given various circumstances, the adjustment to market standards is uneven. The shift towards the "western model" of rewarding work has been apparently more rapid in new private firms and foreign-owned companies. Also, public services have seen an uneven rise in earnings, some of which are advancing (in finance, public administration, justice), while others lag behind (in health and social services, education and research).

Important questions remain, however, open: how far all changes that have occurred so far are not only formal but substantial; to what degree they guarantee a better matching of competent people to responsible jobs; what their impact is on the productivity of labor; how they contribute to the creation of incentives to work well and manage rationally, and; how they improve the efficiency of the economy as a whole? In fact, there is no guarantee that higher disparities ensure more and better work, that more years of schooling bring a higher productivity of labor and that more space left for "market" characteristics of workers in wage determination will be actually used for improvement of work and management incentives. Only one observed result can be taken as a certainty: that after decades of stagnation the whole earnings and incentive structure is currently in motion and that this motion provides a unique opportunity for the development of an open market economy. 


\section{Introduction}

Through ownership restructuring and the liberalizing of labor contracts, the economic reforms since 1989 has also introduced pronounced movements in earnings distribution and structure in the Czech Republic. In continuation of our previous studies (Vecernik, 1991 and 1995), we offer here a more recent picture of the range of earnings disparities and their sources. We ask how much the returns to education were increased and work incentives strengthened, and in what extent the Czech wage structure has adjusted to advanced capitalist countries regarding the range and main factors of disparities. Unfortunately, only some of these questions can be answered in full extent. This is because the database of wage surveys is rather limited and only a few variables can be analyzed in a consistent cross-time and cross-national comparison.

In the first part of this study, we look at the level of wage inequality and observe the main factors of disparities in the Czech Republic. In the second part, we present available evidence for crossnational comparison. We document that 1 . the introduction of the market economy led to a significant increase in earnings disparities; 2 . the "communist" demographic determination of earnings is being replaced in a great deal by "capitalist" characteristics of workers; 3 . the former "socialist" preferences for the secondary sector are disappearing in favor of a better wage position of the tertiary sector, however uneven among branches; 4 . while political privileges are disappearing, ownership disparities become important, and 5. earnings structure approaches to the model characteristic for Western countries.

Throughout the text, we try to capture change in earnings distribution as a qualitative and systemic change. This is tentatively summarized in Schema 1. It suggests that the whole context of generating disparities in earnings is changing, starting by the general economic goal which proceeds from so-called "extensive" growth with little regard to costs to so-called "intensive" growth involving much better use of resources, including human capital. Instead communist equalization where little disparities reflected mostly reproduction costs of workers (with main attention to heavy manual work), market differences appear which reflect better individual contribution to productivity of labor and efficiency of production. However, no jumps have occurred in fact - the two columns of Schema 1 depict model pictures representing approximation of much more complicated and blurred reality.

\section{Earnings disparities in economic transition}

The transition to a market economy has opened great opportunities for private entrepreneurship, employment in foreign firms, and awards of higher managerial positions. High earnings were accorded to employees in finance and the top echelons of bureaucracy. The possibility was opened for rewarding work differently according to skills and performance. Newly established and foreign firms have had greater liberty in wage settings, and sought to attract highly skilled people by offering considerably higher wages. Job mobility increased as individuals found better-paid jobs, were promoted in de novo private firms or sought work abroad. After state wage regulation was removed, formerly state-owned companies also began to have greater discretion in rewarding their employees. All of this contributed to a general de-equalizing trend in wages.

The rise in disparities was attenuated by some adverse measures. A previously non-existent minimum wage was set in 1991 and increased soon thereafter. However, it was kept frozen for the next following years and it was only in 2000 under Social-Democratic rule that the minimum wage 
crossed the official subsistence minimum for an individual adult. Wage growth continued to be controlled until 1992, when wages were partially liberalized, but regulation has continued in a less strict form for state-owned firms. After a lack of any controls in the beginning of 1993, tax-based wage regulation was re-introduced, but then completely removed in 1995. The fact that the conduct of firms has not changed since that time may be taken as a proof of the actual uselessness of this way of wage restraint (Flek, 1996).

\section{Empirical evidence}

The most obvious data source on earnings are wage statistics based on an inquiry among firms. The coverage of this survey has changed over time. Until 1992, only companies with 100 and more employees were included; since 1992, firms with more than 25 workers and since 1997, firms with more than 20 workers were included. Banking and insurance and public organizations were included without limit. Whereas between 1993-1995, information on wage distribution was estimated combining various sources, in 1996 and 1997 wage surveys were again collected as a sample survey for units with 1-999 employees and full coverage of larger organizations, following recommendations of the Eurostat. Since 1998, database of Information System on Average Wage administered by private company Trexima for the Ministry of Labor and Social Affairs has been used instead of wage surveys.

The wage statistics produced by the Czech Statistical Office (CSO hereafter) or under its control is surely the best source for presenting basic figures on changes in earnings disparities over time. However, given our main focus on distributional issues and the effort to identify various factors affecting wage distribution, we need to use microdata and produce original analyses. For our purpose, the best source are the "personal" files of household income surveys - Microcensuses from years 1988, 1992 and 1996. Their advantage is that they are conducted on large samples fully representative of the entire population. The disadvantage is, however, that they do not include important variables such as industry or the occupation of an individual, except for the last (1996) survey. An additional problem is that whereas before 1989, wages were provided by employers, they are only reported by respondents thereafter.

The dependent variable in our analyses is earnings, meaning all forms of wage and salary incomes from dependent labor gross of employee taxes but net of employer taxes. In some explicit cases, we also include self-employed income. Such a definition of earnings conforms to the Luxembourg Income Study definition as it is used in Smeeding and Coder (1993) which is then suitable for crossnational comparison. For the sake of comparability with wage statistics and comparison over time, we limit our analysis of Microcensus data on the full-time labor force by excluding cooperative farmers. The reasons are that this latter group was never included in wage surveys and was exempted from the wage tax under communist regime and nearly disappeared after 1989.

For some additional variables and questions, we can use also sociological surveys. For the early phase of transition, the survey Social Stratification in Eastern Europe after 1989 is sometimes used (Chase, 1998; Vecernik, 1996). For longitudinal observation, the 1990-1998 series Economic Expectations and Attitudes (EEA) can serve where in some surveys a set of employment variables is included such as ownership status and the size of firm, trade union membership and secondary jobs, etc. (Flanagan, 1995; Vecernik, 1996; Lorenz, Hraba and Pechacova, 1999). Another are the 1992 and 1999 ISSP modules on Social Inequalities including also retrospective self-assessment on income position. Yet another is the survey SIALS (Second International Adult Literacy Surveys) which allows to add literacy skills to standard human capital set of variables (Vecernik, 1999). 


\section{Overall inequality}

All available data witness that since 1989, earnings inequality has been set into motion. According to wage surveys, the decile ratio rose in 1989-1999 from 2.45 to 2.8, i.e. by 14 percent. According to Microcensus data, the decile ratio increased in 1988-1996 from 2.44 to 3.11, i.e. by 27 percent. However, we have to bear in mind that the decile ratio, which is the ratio of the lower bound value of the tenth decile to the upper bound value of the first decile of wage distribution does not take into account earnings of the lowest and highest ten percent of receivers. If we relate the averages of the upper and lower ten percent, then the ratio appears even higher and the change over time looks more important. Various sources converge to estimate 6:1 as the ratio of high to low average income decile in mid 1990s, which is almost twice as much as it was in 1989 (Table 1).

Statistical evidence on inequality of earnings after 1989 is not unambiguous. According to wage statistics, the widening of disparities occurred in various periods differently. Whereas up to 1992, the fastest changes were associated with high categories which moved upwards, after 1992 there were also low wages which began to move downwards. However, neither statistical wage surveys conducted later, nor sociological surveys confirm a considerable drop of low-wage categories in relative terms. What is certainly sure is that the top category of income distribution has considerably increased its share while the income bottom category was stable or only slowly moving upwards. This means that differences in the middle of earnings distribution relatively narrowed and the bulk of income disparities remained compressed.

Change in the overall range of earnings informs us about the abstract "space of inequality", but not about concrete disparities themselves with their meanings and factors. A more important question than how large the differences in earnings are in general is how they do actually "work" within the labor market and business environment by rewarding various dimension of jobs and workers. A related question is in which direction the concrete differences are moving. Unfortunately, such a picture can be presented in much fewer dimensions that we would wish and need, given the limited availability of workers' characteristics in wage statistics and income surveys.

\section{Demographic factors}

The weak status of skilled labor, dominance of political criteria, and application of the "needs principle" under the communist regime resulted in a far greater prevalence of demographic characteristics of workers over economic ones in determining the level of earnings. Particularly in the Czech Republic, gender was the far most important explanatory variable of wage disparities. Age was also important because of the coincidence of its generational and career meanings. The "founders of the communist regime" (youth of 1948) were treated preferentially whole their lives. Together with it, older age served as a "special qualification" for top management. Unlike gender and age, high skills and special job requirements had much lower importance (Vecernik, 1991).

Regression analyses of 1988 and 1996 data document extensive or even revolutionary changes in the earnings structure (Tables 2a and 2b). While in 1988, the sole gender explained 30.5 percent of the variance of earnings, its weight dropped to a mere 12.6 percent in 1996 . This obviously does not mean that the gender wage gap decreased that dramatically, but it suggests that the importance of this dimension has diminished in the context of the thoroughly changing earnings structure. Also, the weight of age variable (5-years categories) halved and the total weight of demographic characteristics (sex and age together) decreased from 40 to 17 percent. In contrast, the explanatory power of education alone (four degrees) has increased from 11 to almost 20 percent. This suggests that in a relatively short time span, education became the most important factor in earnings variance. 
The regression analysis done separately for men and women shows some dissimilarities. The weight of age is still somewhat greater among men than by women, while education is somewhat more important for women than men. Both demographic factors taken together determine women's earnings to a greater degree than men's earnings. By comparing sums of univariate $R^{2}$ with the multivariate additive results, we see than among men, the former is higher than the latter, by contrast with women where the opposite is true. Also results of the SIALS survey support the hypothesis that while with men characteristics of education and experience function relatively separately and, therefore, one could be then replaced by other, both job requirements shall be met by women simultaneously.

Unfortunately, available data do not allow us to show more detailed results, concretely indicating which characteristics of workers actually fill up the space left by decreasing effects of sex and age, which are not fully compensated by the increasing effect of education. We might speculate that instead of being determined by demographic characteristics, earnings are more determined by occupation, industry and the sector of ownership. This cannot be analyzed on homogeneous data across time, because the variable occupation based on the first two-digits of the ISCO code (28 categories), as well as detailed variable of industry, were included only in 1996 survey. The only way to recover this deficiency is to use a retrospective information, such as Daniel Munich, Jan Svejnar and Katherine Terrell provided (1999). However, income retrospect can be biased by usual overestimation of past earnings and underestimation of current earnings.

\section{Returns to education and experience}

According to the theory of human capital, education and experience determine the productivity of labor and, consequently, also the worker's earnings (Becker, 1964). From this point of view, communist Czechoslovakia was among those countries where the importance of education was the most downgraded. This was true not only in comparison with the advanced West, but also with other Central-East European (CEE hereafter) countries. After a period so unfriendly to the evaluation of human capital and investment into it, one can expect a reactionary effect and a rapid increase of rewards to those with higher levels of education, despite the problematic nature of skills and diplomas received in the communist era.

Disparities according to education have increased significantly during the transformation period. Relative to the average, workers with only an elementary education (which is, however, a rapidly disappearing category) saw a decline from 90 to 70 percent of the average in 1988-1996 while university-educated workers strengthened their wage position from 134 in 1988 to 165 percent in 1996. The range of disparities between workers with an elementary and with a university education for both sexes increased from 1.48 to 2.37 in the same period, and was somewhat higher for men than for women in 1996. The greatest absolute and relative increase was registered by both men and women having university education (Table 3 ).

To measure changing return to education and experience according to a standard procedure, we use Mincerian equations (Mincer, 1974) written as:

$\ln (y)=b_{0}+b_{1} s+b_{2} e+b_{3} e^{2}$,

where $\ln (y)=$ natural logarithm of earnings, $s=$ years of schooling and $e=$ years of experience. As usual, the schooling variable is calculated by taking the years needed on average to get the degree reported in the survey, while experience is calculated as age minus schooling minus six. In order to distinguish among returns of various educational levels we use another equation in the form 
$\ln (y)=b_{0}+b_{1} s v+b_{2} s s+b_{3} s u+b_{4} e+b_{5} e^{2}$,

where $b_{1} s v=$ dummy for vocational training, $b_{2} s s$ dummy for high school and $b_{3}=$ dummy for university education, with elementary education as an omitted category.

We have to note that over the actual lifetimes of the individuals surveyed in the sample, the education system was repeatedly restructured. To homogenize various systems of schooling, we thus averaged elementary education (the reference group) as corresponding to eight years of compulsory schooling from the age of six, followed either by vocational school (three years) or secondary school (four years) and university (another four to five years). The data do not distinguish post-graduate qualifications which is still quite rare in the country. All earnings functions are estimated by ordinary least squares (OLS).

At the end of the communist era, one year of schooling increased men's earnings by 4.0 percent and women's earnings by 5.1 percent. In 1992, this figure increased to 6.1 percent for men and 8.0 for women; in 1996, the return already amounted to 8.3 percent for men and 9.4 for women.

Simultaneously, the effect of experience (years on the job) on earnings was stagnating. Whereas in 1988, the effect of experience (or, rather, the joint effect of a person's age and his/her generation) were nearly as strong as those of education for men, education clearly dominated over experience in 1996 (Table 4).

Our results are basically consistent with other observations. According to Filer, Jurajda and Planovsky (1999), who used a database of firms, return to education for men in the Czech Republic amounted to 8.1 percent in 1995 and 9.0 in 1997. However according to Munich, Svejnar and Terrell, who used a special survey, which reached households containing 4,700 individuals in the labor force, the return to education in 1996 amounted only 5.8 percent by men and 7.0 by women which is rather low and close to the Microcensus figures for 1992 (Munich, Svejnar and Terrell, 1999). The underestimation of disparities according to education are otherwise quite common also in sociological surveys where people tend to respond by estimating net rather than gross earnings, even if they are asked for the latter.

\section{Earnings by industry}

After 1989, regressive changes occurred in agriculture, manufacturing and transport. The position of the tertiary branches, however, improved somewhat. Trade and catering, health and social services slightly improved their earnings position, while education, research and culture completely stagnated. The most apparent change is the expansion of the banking sector, which advanced considerably by utilizing all possible means, even by paying penalties for overstepping the limit of allowed wage increases. In the last two years, health services, education and administration experienced several wage fluctuations: they improved their position slightly in early 1990s, but then slide backwards again reaching the lowest figures in 1998; in 1999, they almost recovered their 1997 positions due to a substantial increase in tariff wages of public sector (Table 5).

Generally speaking, wage shifts according to industry led to a diminishing significance of this dimension of income distribution relatively to others: today there are certainly much more intrathan inter-branch disparities in income than before 1989. Earnings differences by branch of employment remain important despite the fact that a significant equalization of the former disparities has occurred. Moreover, as we stated above, the available statistics does not present all changes in branch disparities, because it did not cover small firms up until 1996. 
While we cannot compare the changing weight of industry dispersion over time, we can at least observe it in comparison with other characteristics of workers in 1996. Regression analysis in Table 6 measures the weight of branch disparities themselves and additively to other variables, following our previous analysis in Table $2 \mathrm{a}$ and $2 \mathrm{~b}$. The sole industry variable (containing ten branches) explains about five percent of all workers' and men's earnings variance, but as much as nine percent of women's earnings variance - for women it is therefore much more important in which branch they are employed. If added to the previously analyzed variables (sex, age and education), branch disparities can explain an additional three percent for both sexes and for men, and four percent for women.

\section{Political factors and ownership}

In the communist regime, political factors exerted a comprehensive influence on earnings. First, they conditioned one's educational level (through controlled access to secondary and, in particular, university education). Secondly, they had a considerable influence on job searches, both through informal social networks and formal channels to managerial positions in low-level organizations and almost all positions in high-level organizations. Third, the application of higher wage tariffs or higher premiums has privileged party members against non-members, even when occupying the same positions. Under the ceteris paribus condition, the residual premium of party membership on earnings amounted to ten percent in 1984, according to a social stratification survey of the time (Vecernik, 1996:57).

The former political dimension of earnings rapidly disappeared in the early transition, although not completely - skills and knowledge formerly acquired in politically determined positions became a precious "social capital" to be used in top jobs in new private business and foreign companies under market conditions. E.g. the first expert engaged by foreign company after 1989 was the last communist Minister of Foreign Trade. As Bogdan W. Mach observed for Poland, "political segmentation of the former state-socialist labor market exerts a strong influence on individuals' placement in the current capitalist market. We discovered that the former middle managerial statuses and not top or lower managerial positions can be effectively exchanged for advantaged positions under the new system - especially for the status of an owner and for greater economic well-being" (Mach, 2000:33).

In the transition period, the political dimension was in some sense "replaced" by differences according to ownership status. Unfortunately, there is no variable in statistical income surveys (including the 1996 Microcensus), which would enable us to add this dimension to variance analysis of earnings. Only one-way averages of wages according to ownership sector are produced by the CSO and such variables are thus available only in special wage or sociological surveys.

The CSO has published wage statistics according to economic sector since 1995. Most differences in earnings are, however, hidden by the categorization used. According to the 1999 results, only a negligible number of workers are employed in the state-owned production firms, but these workers have wages substantially higher than those in the private business sector. On the whole, there is almost no substantial difference between the domestic private and state sectors (both displaying about 95 percent of the average), while earnings in companies with the participation of foreign capital are much higher: 132 percent of the average in foreign firms (about 150,000 workers), 128 percent in international firms (200,000 workers) and 116 percent in mixed firms (500,000 workers) are reported by the statistical wage survey in 1999 (Wage differentiation 2000). 
However, wage averages do not answer the question how in various sectors of ownership education is rewarded. Processing individual data, Filer, Jurajda and Planovsky (1999) distinguished private, state and foreign firms in the Czech Republic and Slovakia in 1995-1997. They found that the university degree is at best rewarded in the private sector throughout the whole period. Rather unexpectedly, the least profitable workplaces for employees with a diploma were foreign-owned firms. General and specialized secondary education are better rewarded in private domestic than in foreign firms, but its position in both is improving over time. In state organizations, specialized secondary education is much better paid than the secondary general. The explanation probably lies in the contrast between professional public services (such as education and health care) and simple administrative jobs.

According to Munich, Svejnar and Terrell, who have analyzed survey among households conducted in 1999, returns to education in individual sectors differ yet again by gender. Whereas for men, the most profitable jobs are in privatized firms (6.5 percent), then in de novo firms (6.1 percent) and last, in state-owned enterprises (5.6 percent), for women the most advantageous are de novo firms ( 8.1 percent), followed by privatized firms ( 7.0 percent) and last again are state-owned enterprises (6.3 percent). It is interesting that wages in the de novo firms are the most determined by education and experience ( $R^{2}=0.247$ for men and 0.352 for women), although here we might rather expect the greatest liberty in wage settings which takes largely into account also not-measured skills and abilities. It seems that these firms do not share the overwhelming enthusiasm for young workers dominating during most of 1990s.

Even in the post-privatization period since mid-1990s, some differences according to education between state, private domestic and foreign firms remain important. However, a thorough analysis of the ownership dimension of earnings disparities would require a better categorization than is provided by statistical surveys. At least, we should be able to distinguish production firms remaining in state hands from public service institutions, as well as differentiating foreign-owned firms from the first phase of transition (restructured from the very beginning) from firms bought by foreign companies in later phases (after the urgent need of a strategic investor has appeared). We also shall distinguish privatized formerly state-owned firms from de novo SMEs.

Such variables were basically described in sociological surveys, but the samples they used are rather small. The 1998 EEA survey document, for instance, wage dominance of privatized firms over notyet-privatized and a greater variability of earnings in the private sector, The 1999 ISSP survey shows the superiority of rewards in foreign-owned firms and inferiority of earnings in public sector, after controlling for sex and education. However, we can hardly expect a completely consistent hierarchy ranking wage disparities following their degree of marketization - for instance, from the not-yet-privatized state enterprises at the wage bottom to foreign-owned companies at the top, with various transitory ownership forms in between. The situation is quickly changing with restructuring process.

\section{Cross-national comparison}

Given that changes in earnings range and structure also contribute to the trajectory of the country to a standard market economy, a question arises: how large is the distance which still remains between the Czech wage structure and that in Western countries and how does this distance differ in various regards? Trying to answer this, we face two difficulties. First, there is no "standard" market economy, but rather national market economies, each with many specificities. Second, there is no all-inclusive source of information allowing us to make a detailed comparative analysis. In the best 
source of microdata, the Luxembourg Income Study (LIS), variables of education, industry and occupation are not comparable or are even missing. Thus, we have to compose the picture from various sources which does not allow us a consistent multivariate analysis.

\section{Overall disparities}

In communist Central Europe, Czechoslovakia and the former East Germany had an exceptionally equal earnings distribution. Unlike Poland and Hungary, where liberalizing changes started already before 1989, little happened in the Czechoslovak economy until 1990. Before 1989, the bottom half of earnings distribution was similar in all CEE countries in 1988, while the upper half of the distribution was less equal in Poland and even more divergent in Hungary than in Czechoslovakia. The same contrast can be observed when comparing Czech data with wage statistics from Germany and France, and an even greater contrast appears vis-a-vis Austria and Great Britain, where earnings distribution is also less equal in the bottom half (Table 7).

Without any particular intention to increase inequality, the economic reforms launched in 1990 started to direct distribution of earnings towards greater disparities. Although this process affected all CEE countries, previous differences between them in income inequality have been largely maintained: dispersion in earnings inequality in the early 1990s was again the greatest in Hungary, still considerable in Poland, and the least in the former East Germany. The split of Czechoslovakia after 1993 has entailed a divergence in the earnings distribution into larger disparities in the rapidly (although only formally) privatized and more marketized Czech Republic and a narrower disparities in the intentionally more statist and welfarist Slovakia.

Table 8 displays changes in wage disparities along a single indicator of decile ratio. This is a simple indicator the advantage of which is an easy availability and clarity, but whose disadvantage is neglecting the lowest and highest wage deciles of workers. Let us remember again that in the Czech Republic, the fastest increase in wages has been in the tenth income decile, which was likely the case in other countries as well. For comparison of over time changes, we gather various sources which are not always completely comparable; we then have to interpret figures cautiously. As Atkinson and Brandolini (2000) remind us, the secondary use of various datasets always involves many uncertainties and leads to differing results.

In our collection, great disparity in Hungary might be suspected that not only full-time jobs were included in the data (despite the explicit statement of a CSO officer). The jump in differences in the Czech Republic in 1993-1995 should also be taken as illusory, because the wage statistics of the time were compiled from various sources instead of a standard survey. If these two years are omitted, we can see a continual, slowly rising wage disparity. As a result of this increase, the Czech Republic locates itself somewhere between the cluster of typically "liberal" and South European countries displaying more inequality, and the cluster of welfarist West and North European countries displaying less inequality.

\section{Returns to education}

Returns to education also reveal considerable international differences. If observing transitory changes, we have to consider the quite opposite forces shaping dynamic markets against static command economy. In a market economy, education is primarily a personal investment which is validated in economic competition where a higher productivity of labor is expected from knowledge capital. In a command economy, education is considered a public good which does not need to be individually rewarded. Although the original hard-line communist ideology ("as you have studied with working-class money, thus the surplus of your work should belong to it") was 
never applied to its full extent, the position of educated workers in communist Europe and especially in former Czechoslovakia was hardly comparable with that in Western countries.

As Table 9 shows, educational disparities in OECD countries differ greatly, with the extreme of welfarist countries (Denmark, Norway) displaying small inequalities and liberal countries (Great Britain, USA) displaying larger inequalities. In our opinion, the reliability of such data is a little doubtful as at least two countries do not fit to the expected picture: Italy with extremely small wage differences and France with disparities that are too large (we refer here back to Table 8 which displays a quite similar range of disparities in both countries). Following this source, educational disparities in the Czech Republic already exceeded the level of the "socially generous" Western countries. Czech disparities among all employees reached the level of Germany, and among men alone, they are about at the level of Italy, Switzerland or Great Britain.

The more widespread higher skills are (which is the case in developed countries), the lower use to be their returns in comparison with lower levels of education (Baudelot and Glaude, 1990). This helps to explain why education in transitory countries might be even better rewarded than in more advanced countries where higher education enrollments are already greater. To the point, Denis $\mathrm{H}$. Sullivan and Timothy M. Smeeding observed that "while there is evidence that sufficiently increased supplies of highly educated workers can reduce or reverse growing education premia, the cross-section evidence is not consistent with the claim that among advanced (OECD) nations higher levels of educational attainment are associated with lower levels of inequality" (Sullivan and Smeeding, 1997:12). While in Sweden, a steady decrease of return to education was documented (Björklund, 2000), the US college wage premium experienced a narrowing in 1970s and increased again in the 1980s, due to development in the private sector (Katz and Krueger, 1991).

In transition countries, education premia are growing simultaneously with the increasing supply of well-educated people. This seems to be a unique case which contradicts the observation of countries where capitalist development was never disrupted. The higher return to education in reform countries should not be necessarily backed by higher labor productivity. As the improvement of the position of educated workers outstrips the restructuring of their jobs and firms, we can seek an explanation in a sort of "political rent" associated with establishing of democratic regime. This regime suppressed the degradation of higher education and spiritual work imposed by the communism. People with higher education are also abundant among the best-paid workers, in reference to whom Kertesi and Köllö (1999:11) speak about a special "privatization gain".

We display quite opposite trends regarding premiums for higher education in reform and advanced countries by overtime changes in four Central European countries (Table 10). In all reform countries, return to education substantially rose, to the greatest extent in the Czech Republic. The opposite is true for Austria. Surprisingly enough, current disparities seem to be quite close in all countries under observation, which is a result of opposing tendencies: while in reform countries wage premiums for educated employees were increasing, in Austria they were decreasing. Even so, the last Austrian figures are already somewhat lower than in the reform countries. On the other side, however, rewards for university education is more distanced from secondary education in Austria than in reform countries.

In fact, comparison of relative returns to education tells us still only little about the actual functioning of the national economy in general and the labor market in particular. A close relationship between the higher productivity of labor of educated workers and their earnings is an assumption of human capital theory. Observing the actual developments in the Czech Republic in 
the 1990s, although returns to education considerably rose, overall productivity of labor was actually falling or has improved only due to reductions in the labor force. In any case, changes in employment were much more important for overall labor productivity than rising earnings disparities. Apparently, there are many more conditions for long-term economic growth than only the profitability of skills, reaching from the macroeconomic background to functioning market institutions and business ethics.

\section{Gender disparities}

According to wage surveys, the gender gap was reduced somewhat in the Czech Republic after 1989. While in 1988, the average wage of full-time female workers was 71 percent of their male counterparts, it rose to 77 percent in 1996 but declined again to 72 percent in 1999, with a tendency towards a slight leveling of disparities in 1999 when it reached 73 percent (Wage differentiation, 2000). However, a more positive trend is registered by using wage median - according to it the relation has increased from 71 in 1988 to 78 in 1997. While low wages of men stagnated and upper wages mounted, the increase in women's wages was more proportionate (Holy, 1999). In those calculation, wages are not adjusted to working hours - even if only full-time jobs are taken into account in wage surveys, women still work fewer hours.

Also in other reform countries, the wage position of women in comparison with men somewhat improved after 1989, as Elizabeth Brainerd (1997) observed, however not on fully consistent and comparable data. The Czech Republic was somewhat backward in the process. As Rutkowski (2000) found, gender variable returned 24 percent-gap in Hungary (1996, data of household panel) and 31 percent in Poland (1996, LFS data). The 1996 Microcensus data (see Table 2a) returns 37 percent, which is by far the highest figure. However, our experience tells us that wages observed by statistical surveys cover, in fact, a lesser share of actual earnings (from all jobs and informal economy) in Hungary and Poland than in the Czech Republic. Therefore, the real gender gap in those countries is likely to be greater than available statistical data show.

As we reported above, although the variance explained by gender differences decreased considerably in the Czech Republic after 1989, wage disparity between men and women still remains considerable. However, the gap does not differ from Western countries substantially. In the mid-1990s, women's gross hourly wages as a percentage of men's varied between 72-74 percent in Southern countries like Portugal and Spain (but also in Austria and the UK), and 87-88 percent in Northern countries like Denmark and Sweden, France, Germany and Italy which are located somewhere in the middle of the range. After allowing for the structural gap, the EU average was 15 percent less for women and even in the age group cohort 25-29, who have had equal access to education and jobs, women's earnings are only 86 percent of men's (Population, 1999). The Czech Republic is thus closer to Southern countries in gross gender gap, which is largely produced by discrimination.

The weight of "discrimination" in total gender gap is estimated by decomposition methods which distinguish between structural differences and the "rest" which can be attributed to a break of equal pay. Some results for Western countries are surprisingly favorable in this sense. In Germany, Monika Jungbauer-Gans (1999) observed that after controlling for job access variables, selfemployed women do not display any earning difference against men, unlike dependent employees. In France, Dominique Meurs and Sophie Ponthieux (1999) calculated on LFS four interesting figures measuring the ratio of women's to men's wage in percent: -23.9 for all employees, -12.4 for full-time employees, -11.4 in addition after controlling for differences in access to any job and only -6.9 after controlling moreover for differences in access to a full-time job. 
In the Czech Republic, the situation is much less favorable than in Western countries. Stepan Jurajda made an original decomposition analysis on 1998 wage surveys from the Czech Republic and Slovakia using both the workers and companies variables. The results show that after including age, education, occupation and firm ownership, one-third of the overall pay difference in the public sector remains attributable to the person's sex, and almost two-thirds are so affected in the private sector. As the author states, this is much higher than e.g. in the USA where the "discrimination" residue amounts to only one third of the entire gap, which is, however, much larger (Jurajda, 2000). In this sense, the Czech Republic is apparently considerably behind the advanced countries.

\section{Conclusion and discussion}

The pre-1989 Czechoslovakia was characterized by earnings equality and, within remaining disparities, by a predominance of demographic features of individuals (gender and age) over their market characteristics (skills and occupation) in determination of earnings. Alongside this, some industries (mining, metallurgy, heavy machinery) were favored, and selected categories of workers (top state and party bureaucracy, army and police officers) privileged. Behind the facade of almost stable range and small overall disparities, demographic factors have been even strengthened and socalled productive industries promoted, while the wage position of higher educated people has declined and the younger generations were disadvantaged in favor of older workers.

After 1989, the transformation process has broken all those tendencies and started to change the established earnings structure. The overall range of inequality in wages has increased, as have returns to education, while the gender gap has somewhat attenuated and the age profile of earnings has became considerably flatter. In the division according to industry, the former administrative "tariff grid" was replaced by market differences in a considerable, however not a full degree. In the public sector, a new and simpler tariff grid has been applied which (again) favors experience above qualification. In most of the private sector, wages are negotiated between employers and trade unions. Lawyers, managers and experts in marketing and other special services to foreign firms already enjoy salaries comparable with their Western counterparts.

Despite a step-by-step adjustment of the earnings structure, the current system is still a mixture of previous features (as the large importance of gender division witnesses), transitory characteristics (displayed especially by disparities among ownership sectors) and a targeted system (which is at best documented by increasing returns to education). Given various circumstances, the adjustment to market standards is uneven. The shift towards the "western model" of rewarding labor has been apparently more rapid in new private firms and foreign-owned companies. Also, public services have seen an uneven rise in earnings, some of which are advancing (in finance, public administration, justice), while others lag behind (in health and social services, education and research). There is also a segment of foreign (most often Ukrainian) workers performing jobs of the lowest prestige in construction and light manufacturing.

Within all limitations, observed tendencies and the cross-national comparison convincingly show that during a relatively short time span, the Czech wage inequality and structure have been in energetic motion directed towards the Western pattern. The decreasing significance of demographic characteristics and increasing importance of education witnesses this most clearly. Here again, as it happens in so many areas of our economic and social life under transformation, important questions appear: how far those changes are not only formal but substantial; to what degree they guarantee a 
better matching of competent people to responsible jobs; what is their impact on the productivity of labor; how they contribute to the creation of incentives to work well and manage rationally, and; how they improve the efficiency of the economy as a whole?

Such questions certainly cross the limits of our contribution and the explanatory power of all available survey variables. Nevertheless, without going into a profound discussion, we can guess that, in fact, there is no guarantee that higher disparities ensure more and better work, that more years of schooling brings a higher productivity of labor and that more space left for "market" characteristics of workers in wage determination will be actually used for improvement of work and management incentives. There are certainly many doubts about all of this, and only one observed result can be taken as a certainty: that after decades of stagnation the whole earnings and incentive structure is currently in motion and that this motion gives a unique opportunity to develop an open market economy. 


\section{Sources used as primary data in the study}

\section{Microcensus surveys}

Large income surveys started in 1958 as regular statistical surveys conducted every 3-5 years on 12 percent samples of households. Data on wages were notified by employers and pension benefits by post offices. Here, we used the 1989 Microcensus conducted by the CSO on a 2 percent random sample $(\mathrm{N}=69,912)$ in March 1989 including yearly incomes in 1988; the 1992 Microcensus, conducted by the CSO on a 0.5 percent random sample $(\mathrm{N}=16,234)$ in March 1993 and including yearly incomes in 1992, and the 1996 Microcensus, conducted by the CSO on a 1 percent random sample $(\mathrm{N}=28,148)$ in March 1997 and including yearly incomes in 1996. In the two later surveys, incomes were not confirmed, but data corrections were made by the CSO. In Table 10, we used also the 1970 Microcensus conducted by the CSO on a 2 percent random sample of the population included in Census of the Population 1970. Our calculations are made on the sample of 14,533 fulltime employees.

\section{ISSP modules on Social Inequalities}

International Social Survey Program (ISSP) is a long-term international research project which is based on international and inter-project cooperation in the areas of the social sciences. Each year, research on one topic is conducted in all participating countries. Data files are archived by the Zentralarchiv für Empirische Sozialforschung at the University of Cologne. In 1992 and 1999, module on social inequality was applied involving opinions about just income distribution and social stratification. Our calculations are made on the sample of 977 respondents in the labor force.

\section{Economic Expectations and Attitudes (EEA)}

The surveys of the Czechoslovak and later only Czech population started in May 1990 and were conducted biannually in 1990-1992 and in following years, annually (1993-1998). Surveys were organised by the team of socio-economics of the Institute of Sociology of the Academy of Sciences headed by Jiri Vecernik. The samples include adults selected by a two-step quota sampling procedure, whereby the region and size of the locality were defined in the first step and gender, age and education in the second. The data was collected by the Center for Empirical Research STEM.

\section{(Second) International Adult Literacy Survey (SIALS)}

A long-term international research project, which originated in 1995 and is backed by Statistics Canada and ETS at Princeton University. The survey is focused on detailed surveying of the socalled functional literacy of adult persons based on testing their ability to understand printed information and use it in everyday life. Czech data were collected by agency SC\&C in December 1997-April 1998 on the sample of 3132 respondents (from 5000 targeted). 


\section{References}

Atkinson, A.B. and Micklewright, J. (1992) The Economic Transformation of Eastern Europe and the Distribution of Income. Cambridge: Cambridge University Press.

Atkinson, A.B. and Brandolini, A. (2000) Promise and pitfalls in the use of 'secondary' datasets: income inequality in OECD countries. Roma: Banca d'Italia. Temi di discussione del Servizio Studi No. 379.

Baudelot, C. and Glaude, M. (1990) Les diplomes payent-ils de moins en moins? Données sociales 1990. Paris: INSEE.

Becker, G.S. (1964) Human Capital. New York: Columbia University Press.

Björklund, A. (2000) Education policy and returns to education. Swedish Economic Policy Review, 7 (1):71-105.

Brainerd, E. (1997) Women in transition: Changes in gender wage differentials in eastern Europe and the former Soviet Union. Luxembourg Income Study, Working Paper No. 171.

Chase, R.S. (1998) Markets for communist human capital: return to education and experience in post-communist Czech Republic and Slovakia. Industrial and Labor Relations Review, 51(3): 401-423.

Festerer, J. and Winter-Ebmer, R. (1999) Returns to education - evidence for Austria. University Linz, Arbeitspapier No. 9913.

Filer, R.K., Jurajda, S. and Planovsky, J. (1999) Education and wages in the Czech and Slovak Republics during transition." Labour Economics, 6 (4):581-593.

Flanagan, R.J. (1995) Wage structures in the transition of the Czech economy. International Monetary Fund, Staff Papers No. 42.

Flek, V. (1996) Wage and employment restructuring in the Czech Republic. Czech National Bank, Working Papers No. 60.

Hofer, H., Pichelmann, K. and Schuh, A.-U. (1999) Price and quantity adjustment in the Austrian labour market. Institute for Advanced Studies, Vienna, Economics Series No. 57.

Holy, D. (1999) Analysis of wage disparities of men and women on the basis of sample survey of employees (in Czech). Statistika, 36 (2):53-68.

Jungbauer-Gans, M. (1999) Der Lohnunterschied zwischen Frauen and Männers in selbständiger und abhängiger Beschäftingungen. Kölner Zeitschrift für Soziologie and Sozialpsychologie, 51 (2):364-390.

Jurajda, S. (2000) Gender wage gap and segregation in late transition. CERGE-EI Discussion Paper No. 34.

Katz, L.F. and Krueger, A.B. (1991) Changes in the structure of wages in the public and private sectors. Research in Labor Economics 12:137-172 (see also Education Matters. Selected Essays by Alan B. Krueger, Edwar Elgar 2000).

Kertesi, G. and Köllö, J. (1999) Economic transformation and the return to human capital. The case of Hungary, 1986-1996. Institute of Economics, Budapest Working Papers on the Labour Market, No. 6.

Krueger, A.B. and Pischke, J.S. (1992) A comparative analysis of East and West German labor market before unification. Discussion Papers of the Zentrum für Europäische Wirtschaftsforschung No. 11. 
Lorenz, F.O., Hraba, J. and Pechacova, Z. (1999) Privatization and income change in the Czech Republic: tensions in the lives of rural and urban employed men. Rural Sociology, 64:693-717.

Lorenz W. and Wagner, J. (1990) A note on returns to human capital in the eighties. Evidence from twelve countries. Luxembourg Income Study, Working Paper No. 54.

Mach, B.W. (2000) Nomenklatura, communist party membership, and advantage on the labor market”. In: K.M. Slomczynski ed., Social Patterns of Being Political. The Initial Phase of the Post-Communist Transition in Poland. Warsaw: IFiS Publishers.

Meurs, D. and Ponthieux, S. (1999) Emploi et salaires: les inégalités entre femmes et hommes en mars 1998. DARES Informations No. 99.08 - 32.2. Paris: Ministere de l'emploi et de la solidarité.

Munich, D., Svejnar, J. and Terrell, K. (1999) Returns to human capital under the communist wage grid and during the transition to a market economy. CEPR Discussion Papers No. 2332.

Population (1999) and social conditions No. 48. Luxembourg: Eurostat.

Puhani, P.A. (1999) All quiet on the wage front? Gender, public-private sector issues and rigidities in the Polish wage structure. Working Paper, Zentrum für Europäische Wirtschaftsforschung, München.

Rutkowski, J. (1994) Labor market transition and changes in wage structure: The case of Poland. Center for International Studies, Princeton University.

Rutkowski, J. (1996) Changes in the wage structure during economic transition in Central and Eastern Europe. World Bank Technical Paper, No. 340. Washington: The World Bank.

Rutkowski, J. (2000) Wage inequality in transition economies of Central Europe. Trends and patterns in the late 1990s. Washington: The World Bank, processed.

Smeeding, T.M. and Coder, J. (1993) Income inequality in rich countries during the 1980s. Luxembourg Income Study, Working Paper No. 88.

Sullivan, D.H. and Smeeding, T.M. (1997) Educational attanment and earnings inequality in eight nations. Luxembourg Income Study, Working Paper No. 164.

Vecernik, J. (1991) Earnings distribution in Czechoslovakia: Intertemporal change and international comparison. European Sociological Review, 6 (2):237-252.

Vecernik, J. (1995) Changing earnings distribution in the Czech Republic. Survey evidence from 1988-1994. Economics of Transition 3, (3):355-371.

Vecernik, J. (1996) Markets and People. The Czech Reform Experience in a Comparative Perspective. Aldershot: Avebury.

Vecernik, J. (1999) Motivational mechanisms of human resources. Chapter IV in: Human Resources in the Czech Republic, Prague: Institute for Information in Education, and the National Educational Fund.

Wage differentiation (2000) of employees (in Czech). Prague: CSO. Series of labor and social statistics No. 31-11-00. 
Schema 1 Earning disparities under command and market economy

\begin{tabular}{|l|l|l|}
\hline Characteristic & Command economy & Market economy \\
\hline General economic goal & $\begin{array}{l}\text { Amount of product } \\
\text { (high-costs growth) }\end{array}$ & $\begin{array}{l}\text { Productivity, efficiency } \\
\text { (low-costs growth) }\end{array}$ \\
\hline Generator of inequality & $\begin{array}{l}\text { The state and (marginally) } \\
\text { the labor market }\end{array}$ & $\begin{array}{l}\text { Labor market and } \\
\text { (considerably) the state }\end{array}$ \\
\hline Distribution according to & $\begin{array}{l}\text { Basic needs, loyalty } \\
\text { to the regime }\end{array}$ & $\begin{array}{l}\text { Skills, performance, } \\
\text { network appartenance }\end{array}$ \\
\hline Main factors of disparities & $\begin{array}{l}\text { Gender, age, } \\
\text { hard manual labour }\end{array}$ & $\begin{array}{l}\text { Human capital, } \\
\text { entrepreneurship }\end{array}$ \\
\hline The role of education & $\begin{array}{l}\text { State investment } \\
\text { generating small } \\
\text { disparities }\end{array}$ & $\begin{array}{l}\text { Individual investment } \\
\text { generating large disparities }\end{array}$ \\
\hline The role of age & $\begin{array}{l}\text { Generation, accummulated } \\
\text { loyalty (linear increase) }\end{array}$ & $\begin{array}{l}\text { Career, accummulated } \\
\text { experience (curvilenear) }\end{array}$ \\
\hline Preferred branches & $\begin{array}{l}\text { Mining, metallurgy, } \\
\text { heavy manufacturing }\end{array}$ & $\begin{array}{l}\text { Finance, top technologies, } \\
\text { professional services }\end{array}$ \\
\hline $\begin{array}{l}\text { Managerial premiums } \\
\text { given for }\end{array}$ & $\begin{array}{l}\text { Political position, } \\
\text { risk aversion }\end{array}$ & $\begin{array}{l}\text { Innovation, } \\
\text { risk taking }\end{array}$ \\
\hline $\begin{array}{l}\text { Public/private sector } \\
\text { distinction }\end{array}$ & No & Important \\
\hline
\end{tabular}


Table 1 Distribution of earnings by deciles (percent and coefficients)

\begin{tabular}{l|rrrr|rrr|rrc}
\hline \multirow{2}{*}{$\begin{array}{l}\text { Deciles and } \\
\text { coefficients }\end{array}$} & \multicolumn{4}{|c|}{$\begin{array}{c}\text { Wage statistics } \\
\text { gross wage }\end{array}$} & \multicolumn{3}{c|}{$\begin{array}{c}\text { Microcensus } \\
\text { gross earnings }\end{array}$} & \multicolumn{3}{c}{$\begin{array}{c}\text { EEA } \\
\text { net earnings }\end{array}$} \\
\cline { 2 - 11 } 1 & 1989 & 1993 & 1997 & 1999 & 1988 & 1992 & 1996 & 1993 & 1996 \\
\hline 1 & 4.7 & 4.4 & 4.6 & 4.4 & 5.3 & 5.0 & 3.9 & 4.8 & 4.4 & 4.3 \\
3 & 6.5 & 5.6 & 5.9 & 5.8 & 6.6 & 6.1 & 5.5 & 5.6 & 5.3 & 5.2 \\
4 & 7.3 & 6.6 & 6.9 & 6.7 & 7.4 & 6.9 & 6.6 & 6.4 & 6.3 & 6.2 \\
5 & 8.2 & 7.4 & 7.7 & 7.5 & 8.3 & 7.7 & 7.5 & 7.2 & 7.1 & 7.2 \\
6 & 9.1 & 8.4 & 8.5 & 8.3 & 9.2 & 8.5 & 8.4 & 8.1 & 7.9 & 7.9 \\
7 & 10.1 & 9.4 & 9.3 & 9.1 & 10.0 & 9.4 & 9.4 & 9.0 & 8.8 & 9.0 \\
8 & 11.0 & 10.7 & 10.2 & 10.1 & 10.9 & 10.4 & 10.4 & 10.5 & 10.0 & 10.1 \\
9 & 12.2 & 12.2 & 11.0 & 11.4 & 12.0 & 11.7 & 11.8 & 12.1 & 11.4 & 11.8 \\
10 & 13.7 & 14.6 & 13.1 & 13.8 & 13.3 & 13.8 & 14.1 & 14.1 & 14.3 & 14.2 \\
Total & 17.2 & 20.7 & 22.8 & 22.9 & 17.0 & 20.5 & 22.4 & 22.2 & 24.5 & 24.1 \\
\hline Ratio 10:1 & 100.0 & 100.0 & 100.0 & 100.0 & 100.0 & 100.0 & 100.0 & 100.0 & 100.0 & 100.0 \\
Robin Hood Index & 3.7 & 4.7 & 5.0 & 5.2 & 3.2 & 4.1 & 5.7 & 4.6 & 5.6 & 5.6 \\
Coefficient Gini & 14.1 & 18.2 & 17.1 & 18.2 & 13.2 & 16.4 & 18.7 & 18.9 & 20.2 & 20.2 \\
\hline
\end{tabular}

Sources: Microcensus 1989, 1992 and 1996; Wage surveys 1989-1997; EEA January 1993 and 1996, and April 1998. Note: Net earnings according to EEA surveys also include self-employed persons. 
Table 2a Regression analysis of ( $(n)$ earnings by sex, age and education: unstandardized coefficients

\begin{tabular}{lcccc}
\hline Independent & \multicolumn{2}{c}{1988} & & 1996 \\
variable & 1 & 2 & 0.358 & 0.369 \\
\cline { 2 - 5 } Sex & 0.380 & 0.366 & 0.177 & 0.108 \\
Age: & & & 0.225 & 0.154 \\
$25-29$ & 0.139 & 0.109 & 0.251 & 0.194 \\
$30-34$ & 0.223 & 0.203 & 0.256 & 0.222 \\
$35-39$ & 0.274 & 0.264 & 0.257 & 0.223 \\
$40-44$ & 0.315 & 0.304 & 0.254 & 0.211 \\
$45-49$ & 0.317 & 0.308 & 0.192 & 0.149 \\
$50-54$ & 0.316 & 0.316 & 0.174 & 0.295 \\
$55-59$ & 0.246 & 0.245 & & 0.157 \\
$60-$ & 0.055 & 0.059 & & 0.421 \\
Education: & & & & 0.746 \\
vocational & & 0.060 & 0.143 & 0.211 \\
secondary & & 0.329 & 0.433 & 0.365 \\
university & 8.212 & 8.103 & 0.172 & \\
Intercept & 0.398 & 0.475 & & \\
Adjusted R2 & & & & \\
\hline
\end{tabular}

Sources: Microcensus 1989 and 1996.

Omitted categories: age up to 24 , elementary education.

All coefficients significant on the level $<0.001$.

Table 2b Regression analysis of ( $\ln$ ) earnings by sex, age and education: summary of adjusted R2

\begin{tabular}{lcccc}
\hline $\begin{array}{l}\text { Independent } \\
\text { variable }\end{array}$ & \multicolumn{2}{c}{1988} & & 1996 \\
\cline { 2 - 5 } Both sexes & univariate & additive & univariate & additive \\
Sex & 0.305 & 0.305 & 0.126 & 0.126 \\
Age & 0.078 & 0.398 & 0.036 & 0.172 \\
Education & 0.111 & 0.475 & 0.195 & 0.365 \\
Men & & & & 0.073 \\
Age & 0.159 & 0.159 & 0.073 & 0.267 \\
Education & 0.096 & 0.244 & 0.210 & 0.040 \\
Women & & & & 0.040 \\
Age & 0.112 & 0.112 & 0.247 & 0.293 \\
Education & 0.145 & 0.276 & & \\
\hline Sources: & & & & \\
\hline
\end{tabular}

Sources: Microcensus 1989 and 1996.

All coefficients significant on the level $<0.001$. 
Table 3 Earnings by education and sex (percent of the average)

\begin{tabular}{lrcrrrrrrc}
\hline \multirow{2}{*}{$\begin{array}{l}\text { Level of } \\
\text { education }\end{array}$} & \multicolumn{3}{c}{ Both sexes } & \multicolumn{3}{c}{ Men } & \multicolumn{3}{c}{ Women } \\
\cline { 2 - 10 } & 1988 & 1992 & 1996 & 1988 & 1992 & 1996 & 1988 & 1992 & 1996 \\
\hline Elementary & 90.5 & 75.7 & 69.6 & 90.5 & 81.0 & 73.0 & 93.1 & 80.3 & 74.6 \\
Vocational & 95.4 & 92.9 & 87.6 & 95.4 & 90.3 & 85.9 & 93.9 & 85.2 & 81.8 \\
Secondary & 101.4 & 103.7 & 106.9 & 102.2 & 104.5 & 110.3 & 104.3 & 112.6 & 112.7 \\
University & 134.0 & 144.0 & 164.7 & 124.6 & 140.0 & 161.3 & 133.1 & 145.4 & 160.7 \\
Average & 100.0 & 100.0 & 100.0 & 100.0 & 100.0 & 100.0 & 100.0 & 100.0 & 100.0 \\
\hline In \% of total & 100.0 & 100.0 & 100.0 & 115.3 & 119.3 & 116.4 & 79.6 & 77.8 & 81.7 \\
\hline Ratio univ/elem & 1.48 & 1.90 & 2.37 & 1.38 & 1.72 & 2.21 & 1.43 & 1.81 & 2.15 \\
\hline
\end{tabular}

Sources: Microcensus 1989, 1992 and 1996. 
Table 4 Returns to education: unstandardized beta coefficients (dependent variable $l n$ gross earnings)

\begin{tabular}{|c|c|c|c|c|c|c|}
\hline Category and variable & 1988 & 1992 & 1996 & 1988 & 1992 & 1996 \\
\hline \multicolumn{7}{|l|}{ Both sexes } \\
\hline Years of school & 0.044 & 0.069 & 0.088 & & & \\
\hline Experience & 0.028 & 0.032 & 0.032 & 0.028 & 0.033 & 0.033 \\
\hline Experience squared/100 & -0.059 & -0.063 & -0.066 & -0.059 & -0.064 & -0.066 \\
\hline $\operatorname{Sex}$ & -0.358 & -0.408 & -0.350 & -0.362 & -0.421 & -0.367 \\
\hline Intercept & 7.692 & 7.738 & 8.341 & 8.072 & 8.319 & 9.077 \\
\hline \multicolumn{7}{|l|}{ Education: } \\
\hline vocational & - & - & - & 0.054 & 0.102 & 0.138 \\
\hline secondary & - & - & - & 0.151 & 0.317 & 0.406 \\
\hline university & - & - & - & 0.381 & 0.576 & 0.737 \\
\hline Adjusted R2 & 0.465 & 0.384 & 0.362 & 0.466 & 0.390 & 0.369 \\
\hline \multicolumn{7}{|l|}{ Men } \\
\hline Years of school & 0.040 & 0.061 & 0.083 & & & \\
\hline Experience & 0.034 & 0.044 & 0.037 & 0.038 & 0.044 & 0.037 \\
\hline Experience squared/100 & -0.074 & -0.092 & -0.077 & -0.082 & -0.092 & -0.077 \\
\hline Intercept & 8.071 & 7.331 & 8.005 & 7.634 & 7.834 & 8.659 \\
\hline \multicolumn{7}{|l|}{ Education: } \\
\hline vocational & - & - & - & 0.043 & 0.098 & 0.166 \\
\hline secondary & - & - & - & 0.124 & 0.260 & 0.391 \\
\hline university & - & - & - & 0.339 & 0.525 & 0.731 \\
\hline Adjusted R2 & 0.253 & 0.222 & 0.274 & 0.264 & 0.224 & 0.278 \\
\hline \multicolumn{7}{|l|}{ Women } \\
\hline Years of school & 0.051 & 0.080 & 0.094 & & & \\
\hline Experience & 0.022 & 0.017 & 0.027 & 0.022 & 0.017 & 0.027 \\
\hline Experience squared/100 & -0.038 & -0.022 & -0.054 & -0.038 & -0.022 & -0.054 \\
\hline Intercept & 6.922 & 6.904 & 7.614 & 7.358 & 7.560 & 8.390 \\
\hline \multicolumn{7}{|l|}{ Education: } \\
\hline vocational & & & & 0.055 & 0.096 & 0.107 \\
\hline secondary & & & & 0.182 & 0.370 & 0.421 \\
\hline university & & & & 0.453 & 0.642 & 0.757 \\
\hline Adjusted R2 & 0.264 & 0.249 & 0.267 & 0.268 & 0.268 & 0.278 \\
\hline
\end{tabular}

Sources: Microcensus 1989, 1992 and 1996.

All coefficients significant on the level $<0.001$ 
Table 5 Earnings by industry of employment (percent of the average)

\begin{tabular}{lrrrrrrrrrrr}
\hline Industry & 1989 & 1990 & 1991 & 1992 & 1993 & 1994 & 1995 & 1996 & 1997 & 1998 & 1999 \\
\hline Manufacturing & 104.4 & 103.8 & 103.6 & 103.5 & 101.3 & 99.9 & 99.7 & 99.1 & 100.5 & 101.4 & 100.1 \\
Construction & 111.2 & 109.9 & 106.6 & 108.2 & 112.3 & 110.6 & 108.1 & 105.1 & 104.9 & 103.3 & 100.6 \\
$\begin{array}{l}\text { Agriculture } \\
\text { Transport and }\end{array}$ & 108.2 & 109.6 & 97.7 & 91.8 & 87.7 & 85.0 & 84.2 & 80.7 & 79.5 & 78.9 & 75.9 \\
communications & 106.4 & 104.6 & 103.2 & 99.1 & 97.5 & 98.7 & 100.8 & 101.8 & 105.8 & 108.1 & 107.8 \\
Trade and catering & 83.8 & 85.0 & 86.2 & 90.1 & 88.6 & 91.6 & 88.4 & 87.8 & 98.1 & 98.2 & 97.6 \\
$\begin{array}{l}\text { Health care and } \\
\text { welfare services }\end{array}$ & 90.1 & 92.6 & 96.6 & 94.5 & 95.0 & 93.9 & 92.1 & 93.7 & 90.0 & 85.1 & 89.4 \\
$\begin{array}{l}\text { Education } \\
\text { Banking }\end{array}$ & 89.8 & 88.1 & 90.3 & 90.6 & 90.3 & 91.7 & 90.9 & 92.9 & 88.1 & 84.2 & 87.5 \\
$\begin{array}{l}\text { and insurance } \\
\text { Administration }\end{array}$ & 98.3 & 102.0 & 136.9 & 169.6 & 177.7 & 175.2 & 171.5 & 169.6 & 174.5 & 181.0 & 181.7 \\
and defense & 101.3 & 100.4 & 105.3 & 114.6 & 117.8 & 120.7 & 117.6 & 118.3 & 110.2 & 103.1 & 107.8 \\
Average & 100.0 & 100.0 & 100.0 & 100.0 & 100.0 & 100.0 & 100.0 & 100.0 & 100.0 & 100.0 & 100.0 \\
\hline
\end{tabular}

Sources: Statistical Yearbooks. 
Table 6 Regression analysis of ( $(n)$ earnings by industry: unstandardized coefficient beta before and after controlling for sex, age and education in 1996

\begin{tabular}{|c|c|c|c|c|c|c|}
\hline \multirow[t]{2}{*}{ Industry } & \multicolumn{2}{|c|}{ Before controlling } & \multicolumn{4}{|c|}{ After controlling } \\
\hline & Both sexes & Men & Women & Both sexes & Men & Women \\
\hline Manufacturing & .196 & .169 & .110 & .210 & .2371 & .174 \\
\hline Construction & .270 & .107 & .269 & .187 & .1957 & .172 \\
\hline Agriculture & .046 & -.043 & .023 & .055 & .0400 & .090 \\
\hline $\begin{array}{l}\text { Transport and } \\
\text { communications }\end{array}$ & .242 & .143 & .232 & .213 & .2031 & .242 \\
\hline Trade and catering & .094 & .183 & .076 & .162 & .2094 & .129 \\
\hline Health and welfare & .141 & .200 & .247 & .156 & .0982 & .152 \\
\hline Education & .180 & .295 & .252 & .064 & .0472 & .052 \\
\hline $\begin{array}{l}\text { Banking } \\
\text { and insurance }\end{array}$ & .707 & .796 & .734 & .587 & .5689 & .584 \\
\hline $\begin{array}{l}\text { Administration } \\
\text { and defense }\end{array}$ & .372 & .340 & .367 & .244 & .2488 & .237 \\
\hline Intercept & 8.911 & 9.100 & 8.748 & 9.015 & 8.6064 & 8.371 \\
\hline Adjusted R2 & .053 & .056 & .091 & .395 & .299 & .335 \\
\hline
\end{tabular}


Table 7 Earnings distribution CEE countries and Western Europe between 1988 and 1992 (percentiles and decile ratio)

\begin{tabular}{|c|c|c|c|c|c|c|c|}
\hline \multirow{2}{*}{$\begin{array}{l}\text { Year and } \\
\text { country }\end{array}$} & \multicolumn{6}{|c|}{ Percentile (percent of median) } & \multirow{2}{*}{$\begin{array}{c}\text { Decile ratio } \\
90 / 10 \\
\end{array}$} \\
\hline & 5th & $10^{\mathrm{th}}$ & 25 th & 75 th & 90th & 95th & \\
\hline \multicolumn{8}{|l|}{1988} \\
\hline Czech R. ${ }^{\mathrm{a}}$ ) & 53.8 & 60.0 & 74.4 & 118.9 & 143.8 & 162.5 & 2.40 \\
\hline Slovakiaa) & 53.6 & 61.7 & 77.0 & 123.2 & 149.3 & 168.0 & 2.42 \\
\hline Hungaryb) & 50.0 & 58.3 & 74.4 & 135.1 & 183.3 & 225.9 & 3.14 \\
\hline Poland $b)$ & 55.4 & 62.7 & 78.2 & 126.3 & 163.3 & 191.6 & 2.60 \\
\hline East Germanyd) & & 68.1 & 82.1 & 121.1 & 141.9 & & 2.08 \\
\hline West Germanyd) & & 62.5 & 78.3 & 129.7 & 173.1 & & 2.77 \\
\hline Austria $\mathrm{f}$ ) & & 51 & & & 181 & & 3.55 \\
\hline Great Britain b) & 47.3 & 54.7 & 72.3 & 137.1 & 183.9 & 226.5 & 3.36 \\
\hline France $\left.{ }^{f}\right)$ & & 65 & & & 194 & & 2.98 \\
\hline \multicolumn{8}{|l|}{$1991 / 1992$} \\
\hline Czech R. a) & 51.2 & 56.1 & 69.6 & 116.7 & 153.5 & 184.2 & 2.74 \\
\hline Slovakia a) & & 68.1 & & & 170.5 & & 2.50 \\
\hline Poland c) & & 61.6 & 77.3 & 132.4 & 179.8 & 219.3 & 2.92 \\
\hline Hungarye) & 48.3 & 56.0 & 72.6 & 145.9 & 203.7 & 257.1 & 3.64 \\
\hline East Germanyd) & & 69.6 & 82.9 & 123.8 & 159.4 & & 2.29 \\
\hline Austriaf) & & 51 & & & 178 & & 3.49 \\
\hline Great Britainb) & & 54.7 & 72.3 & 137.1 & 183.9 & 226.5 & 3.36 \\
\hline France $\mathrm{f}^{\mathrm{f}}$ & & 65 & & & 196 & & 3.02 \\
\hline
\end{tabular}

Sources:

a) Microcensus 1989 and 1992.

b) Atkinson and Micklewright, 1992.

c) Rutkowski, 1994.

d) Krueger and Pischke, 1992.

e) Personal communication of the Statistical Office.

f) OECD Economic Outlook 1993. 
Table 8 Disparities in earnings in OECD countries (decile ratio 90/10)

\begin{tabular}{lccccccccc}
\hline Country & 1980 & 1985 & 1989 & 1992 & 1993 & 1994 & 1995 & 1996 & 1997 \\
\hline Czech Republic & & 2.52 & 2.45 & 2.74 & $(3.19)$ & $(3.14)$ & $(3.73)$ & 2.82 & 2.80 \\
Hungary & 2.39 & 2.64 & 3.14 & 3.64 & 3.59 & 4.16 & & 3.19 \\
Poland & 2.88 & 2.70 & 2.43 & 2.9 & 3.0 & 3.4 & 3.4 & 3.5 & 3.5 \\
East Germany & & & 2.08 & 2.29 & & & & & \\
West Germany & 2.67 & & 2.45 & 2.44 & 2.32 & & 2.37 & \\
Austria & 2.61 & & 3.55 & 3.54 & 3.58 & 3.66 & & & \\
Belgium & 2.01 & & 2.36 & 2.29 & 2.25 & 2.08 & & \\
Denmark & 2.14 & 2.17 & 2.18 & 2.17 & & & & \\
France & 3.08 & 3.12 & 3.28 & 3.23 & 3.26 & 3.28 & & \\
Italy & 2.64 & 2.50 & 2.16 & & 2.77 & & 3.11 & \\
Netherlands & & 2.89 & 3.05 & 3.08 & & 3.04 & 2.57 & \\
Portugal & & 3.62 & 3.49 & 3.96 & 4.05 & & 3.96 & \\
Sweden & 2.04 & 2.07 & 2.12 & 2.10 & 2.13 & & & \\
Switzerland & & & 2.72 & 2.67 & 2.71 & 2.65 & 2.72 & \\
Great Britain & 2.79 & 3.06 & 3.28 & 3.31 & 3.33 & 3.31 & 3.38 & \\
USA & & & & & 4.16 & 4.35 & 4.39 & \\
Japan & 3.01 & 3.11 & 3.16 & 3.03 & 3.04 & 3.02 & & \\
\hline
\end{tabular}

Sources:

Czech Republic - Wage surveys of the CSO (figures in parentheses based on estimates whose reliability is limited). Hungary - Atkinson and Micklewright, 1992; since 1992 personal communication of Elizabeth Lindner (CSO).

Poland - Atkinson and Micklewright, 1992; Rutkowski, 2000.

East Germany - Krueger and Pischke, 1992.

Other countries - OECD Economic Outlook, 1993, 1996.

Figures of 1995 for West Germany, France, Netherlands and Portugal see OECD DEELSA/ELSA/WP7(99)4.

OECD Economic Survey Czech Republic 1998 reports for Austria 1994 different figure than OECD Economic Outlook - 2.95. Austrian Microcensus 1997 returns much lower figures for dependent workers than are reported by OECD. 
Table 9 Disparities in earnings by education in OECD countries about 1995 (in percent of earnings of secondary educated workers)

\begin{tabular}{|c|c|c|c|c|c|c|c|c|c|}
\hline \multirow[t]{2}{*}{ Country } & \multicolumn{3}{|c|}{ Lower education } & \multicolumn{3}{|c|}{ Tertiary education } & \multicolumn{3}{|c|}{ The ratio tertiary/lower } \\
\hline & Total & Men & Women & Total & Men & Women & Total & Men & Women. \\
\hline Czech Republic & 78 & 75 & 69 & 151 & 143 & 138 & 1.94 & 1.91 & 2.00 \\
\hline Germany & 76 & 82 & 82 & 158 & 152 & 151 & 2.08 & 1.85 & 1.84 \\
\hline Denmark & 84 & 86 & 87 & 134 & 138 & 132 & 1.59 & 1.60 & 1.53 \\
\hline Finland & 93 & 91 & 93 & 187 & 190 & 174 & 2.01 & 2.09 & 1.87 \\
\hline France & 82 & 85 & 79 & 178 & 185 & 167 & 2.17 & 2.18 & 2.11 \\
\hline Ireland & 85 & 77 & 62 & 183 & 171 & 187 & 2.15 & 2.22 & 3.02 \\
\hline Italy & 77 & 74 & 74 & 134 & 142 & 120 & 1.74 & 1.92 & 1.62 \\
\hline Netherlands & 86 & 87 & 77 & 137 & 135 & 143 & 1.59 & 1.55 & 1.86 \\
\hline Portugal & 64 & 62 & 64 & 184 & 182 & 175 & 2.88 & 2.94 & 2.73 \\
\hline Sweden & 90 & 88 & 89 & 153 & 158 & 144 & 1.70 & 1.80 & 1.62 \\
\hline Switzerland & 71 & 80 & 75 & 161 & 146 & 161 & 2.27 & 1.82 & 2.15 \\
\hline Great Britain & 74 & 79 & 69 & 181 & 161 & 190 & 2.44 & 2.04 & 2.75 \\
\hline USA & 67 & 64 & 64 & 183 & 183 & 175 & 2.73 & 2.86 & 2.73 \\
\hline
\end{tabular}

Sources: OECD. Figure of the Czech Republic recalculated according to Microcensus 1996.

Note: Only persons 25-64 years old are included. 
Table 10 Wage premiums for individual levels of education and for one year of schooling in three transition countries and Austria (percent)

\begin{tabular}{|c|c|c|c|c|c|c|}
\hline \multicolumn{2}{|c|}{ Country and year } & Primary & $\begin{array}{c}\text { Vocati- } \\
\text { onal }\end{array}$ & $\begin{array}{l}\text { Secon- } \\
\text { dary }\end{array}$ & $\begin{array}{l}\text { Univer- } \\
\text { sity }\end{array}$ & $\begin{array}{l}\text { One year } \\
\text { of school }\end{array}$ \\
\hline \multicolumn{7}{|c|}{ Czech Republic } \\
\hline & 1970 & reference & 4.9 & 12.8 & 32.3 & 3.0 \\
\hline & 1988 & reference & 5.4 & 15.1 & 38.1 & 4.4 \\
\hline \multirow[t]{5}{*}{ All } & 1992 & reference & 10.2 & 31.7 & 57.6 & 6.9 \\
\hline & 1996 & reference & 13.8 & 40.6 & 73.7 & 8.8 \\
\hline & 1996 & reference & 11.9 & 39.8 & 93.6 & 11.1 \\
\hline & 1970 & reference & 3.6 & 14.1 & 30.1 & 3.0 \\
\hline & 1988 & reference & 4.3 & 12.4 & 33.9 & 4.0 \\
\hline \multirow[t]{5}{*}{ Men } & 1992 & reference & 9.8 & 26.0 & 52.5 & 6.1 \\
\hline & 1996 & reference & 16.6 & 39.1 & 73.1 & 8.3 \\
\hline & 1996 & reference & 15.8 & 40.3 & 94.4 & 10.9 \\
\hline & 1970 & reference & 7.2 & 11.3 & 34.2 & 2.9 \\
\hline & 1988 & reference & 5.5 & 18.2 & 45.3 & 5.1 \\
\hline \multicolumn{2}{|c|}{ Women 1992} & reference & 9.6 & 37.0 & 64.2 & 8.0 \\
\hline \multicolumn{2}{|c|}{1996} & reference & 10.7 & 42.1 & 75.7 & 9.4 \\
\hline & 1996 & reference & 7.8 & 39.3 & 96.7 & 11.4 \\
\hline \multicolumn{7}{|c|}{ Hungary } \\
\hline \multirow[t]{3}{*}{ Men } & 1989 & reference & 11.6 & 24.8 & 67.8 & - \\
\hline & 1992 & reference & 14.5 & 34.9 & 83.9 & - \\
\hline & 1996 & reference & 14.5 & 32.9 & 86.8 & - \\
\hline \multicolumn{2}{|c|}{ Women 1989} & reference & 12.8 & 26.0 & 74.1 & - \\
\hline \multicolumn{2}{|c|}{1992} & reference & 14.2 & 35.7 & 86.7 & - \\
\hline \multirow{2}{*}{\multicolumn{7}{|c|}{1996}} \\
\hline & & & & & & \\
\hline & 1987 & & - & - & - & 5.0 \\
\hline \multirow[t]{2}{*}{ All } & 1992 & & - & - & - & 7.9 \\
\hline & 1996 & & - & 34.0 & 77.4 & 7.3 \\
\hline \multirow[t]{2}{*}{ Men } & 1992 & -9.3 & reference & $(-4.1)-8.6$ & 29.7 & - \\
\hline & 1995 & -10.3 & reference & 7.6-13.6 & 44.1 & - \\
\hline \multicolumn{2}{|c|}{ Women 1992} & -8.6 & reference & $14.2-15.8$ & 30.2 & - \\
\hline \multicolumn{2}{|c|}{1995} & -3.5 & reference & 7.4-12.3 & 43.2 & - \\
\hline \multicolumn{7}{|c|}{ Austria } \\
\hline \multirow{5}{*}{ Men } & 1981 & reference & 9.7 & 33.0 & 67.2 & 10.3 \\
\hline & 1989 & reference & 10.6 & 33.1 & 60.7 & 9.7 \\
\hline & 1993 & reference & 10.7 & 26.0 & 61.2 & 9.4 \\
\hline & 1995 & reference & - & - & - & 6.9 \\
\hline & 1997 & reference & - & - & - & 7.4 \\
\hline \multirow{5}{*}{ Wom } & 1981 & reference & - & - & - & 11.6 \\
\hline & 1989 & reference & - & - & - & 10.4 \\
\hline & n 1993 & reference & - & - & - & 8.9 \\
\hline & 1995 & reference & - & - & - & 6.1 \\
\hline & 1997 & reference & - & - & - & 8.0 \\
\hline
\end{tabular}

Note: In Poland and Austria general secondary education is taken as secondary level. 
Sources:

Czech Republic - Microcensus 1970, 1989, 1992 and 1996 (budget and non-budget sectors, controlled for sex, experience, experience ${ }^{2}$; the other line for 1996 in italics controlled for industry and region as well).

Hungary - Kertesi and Köllö, 1999 (non-budget sector, controlled for sex, experience, experience ${ }^{2}$, occupation, productivity, capital/labor ratio, firm size, industry).

Poland - figures on all employees according to Rutkowski, 2000 (budget and non-budget sectors, controlled for sex , experience, experience ${ }^{2}$, industry); figures on men and women according to Puhani, quoted by Kertesi and Köllö,1999 (budget sector, controlled for experience, experience ${ }^{2}$, occupation, residence, industry, household type, local unemployment rate, previous employment status and disability); last column according to Rutkowski, 2000 (budget and non-budget sectors, controlled for sex, experience, experience ${ }^{2}$, industry).

Austria - figures for individual education level according to Hofer, Pichelmann and Schuh, 1999 (non-budget sector, controlled for sex, experience, experience ${ }^{2}$ ), figures for return of schooling according to Fersterer and Winter-Ebmer, 1999 (budget and non-budget sectors, controlled for sex, experience, experience ${ }^{2}$; figures in italics controlled for family background, nationality, region, city size and industry as well). 


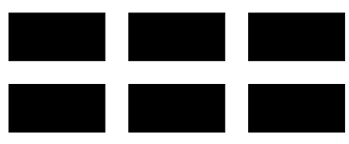

THE WILLIAM DAVIDSON INSTITUTE

AT THE UNIVERSITY OF MICHIGAN BUSINESSSCHOOL

\section{DAVIDSON INSTITUTE WORKING PAPER SERIES - Most Recent Papers}

The entire Working Paper Series is available at: www.wdi.bus.umich.edu

CURRENT AS OF 5/01/01

\begin{tabular}{|c|c|c|}
\hline Publication & Authors & Date \\
\hline $\begin{array}{l}\text { No. } 373 \text { Earnings Disparities in the Czech Republic: Evidence of the } \\
\text { Past Decade and Cross-National Comparison }\end{array}$ & Jiri Vecernik & May 2001 \\
\hline $\begin{array}{l}\text { No. } 372 \text { Economic Reform, Democracy and Growth During Post- } \\
\text { Communist Transition }\end{array}$ & Jan Fidrmuc & Mar. 2001 \\
\hline $\begin{array}{l}\text { No. } 371 \text { Do Multinational Enterprises Substitute Parent Jobs for Foreign } \\
\text { Ones? Evidence from Firm Level Panel Data }\end{array}$ & Jozef Konings and Alan Murphy & Apr. 2001 \\
\hline $\begin{array}{l}\text { No. } 370 \text { From Needs to the Market: Changing Inequality of Household } \\
\text { Income in the Czech Transition }\end{array}$ & Jiri Vecernik & Apr. 2001 \\
\hline $\begin{array}{l}\text { No. } 369 \text { Competition and Corporate Governance: Substitutes or } \\
\text { Complements? Evidence from the Warsaw Stock Exchange }\end{array}$ & $\begin{array}{l}\text { Irena Grosfeld and Thierry } \\
\text { Tressel }\end{array}$ & Mar. 2001 \\
\hline $\begin{array}{l}\text { No. } 368 \text { Multinational Corporations as Catalyst for Industrial } \\
\text { Development: The Case of Poland }\end{array}$ & $\begin{array}{l}\text { Carlo Altomonte and Laura } \\
\text { Resmini }\end{array}$ & Feb. 2001 \\
\hline No. 367 A Multi-Task Theory of the State Enterprise Reform & $\begin{array}{l}\text { Chong-En Bai, David D. Li, } \\
\text { Zhigang Tao, and Yijiang Wang }\end{array}$ & Mar. 2001 \\
\hline No. 366 Confidence Building in Emerging Stock Markets & $\begin{array}{l}\text { Enrico C. Perotti, Luc Laeven, } \\
\text { and Pieter van Oijen }\end{array}$ & Dec. 2000 \\
\hline $\begin{array}{l}\text { No. } 365 \text { Incentive Contracting versus Ownership Reforms: Evidence } \\
\text { from China's Township and Village Enterprises }\end{array}$ & $\begin{array}{l}\text { Chun Chang, Brian McCall, and } \\
\text { Yijang Wang }\end{array}$ & Nov. 2000 \\
\hline $\begin{array}{l}\text { No. } 364 \text { Individual Pay and Outside Options: Evidence from the Polish } \\
\text { Labour Force Survey }\end{array}$ & $\begin{array}{l}\text { Fiona Duffy and Patrick Paul } \\
\text { Walsh }\end{array}$ & Mar. 2001 \\
\hline $\begin{array}{l}\text { No. } 363 \text { Investment, Credit Rationing and the Soft Budget Constraint: } \\
\text { Evidence from Czech Panel Data (revised Davidson Institute Working } \\
\text { Paper No. 60a) }\end{array}$ & Lubomír Lízal and Jan Svejnar & Feb. 2001 \\
\hline $\begin{array}{l}\text { No. } 362 \text { A Network Perspective on Inter-Organizational Transfer of } \\
\text { R\&D Capabilities: A Study of International Joint Ventures in Chinese } \\
\text { Automobile Industry }\end{array}$ & $\begin{array}{l}\text { Zheng Zhao, Jaideep Anand and } \\
\text { Will Mitchell }\end{array}$ & Feb. 2001 \\
\hline $\begin{array}{l}\text { No. } 361 \text { Network Restructuring and Firm Creation in East-Central } \\
\text { Europe: A Public-Private Venture }\end{array}$ & Gerald A. McDermott & Dec. 2000 \\
\hline $\begin{array}{l}\text { No. } 360 \text { Responses of Private and Public Schools to Voucher Funding: } \\
\text { The Czech and Hungarian Experience }\end{array}$ & $\begin{array}{l}\text { Randall K. Filer and Daniel } \\
\text { Münich }\end{array}$ & Oct. 2000 \\
\hline $\begin{array}{l}\text { No. } 359 \text { Labor Market Uncertainty and Private Sector Labor Supply in } \\
\text { Russia }\end{array}$ & Steven Stillman & Sept. 2000 \\
\hline $\begin{array}{l}\text { No. } 358 \text { Russian Roulette-Expenditure Inequality and Instability in } \\
\text { Russia, 1994-1998 }\end{array}$ & Branko Jovanovic & Sept. 2000 \\
\hline No. 357 Dealing with the Bad Loans of the Chinese Banks & John P. Bonin and Yiping Huang & Jan. 2001 \\
\hline No. 356 Retail Banking in Hungary: A Foreign Affair? & John P. Bonin and István Ábel & Dec. 2000 \\
\hline $\begin{array}{l}\text { No. } 355 \text { Optimal Speed of Transition: Micro Evidence from the Czech } \\
\text { Republic }\end{array}$ & $\begin{array}{l}\text { Stepan Jurajda and Katherine } \\
\text { Terrell }\end{array}$ & Dec. 2000 \\
\hline No. 354 Political Instability and Growth in Dictatorships & $\begin{array}{l}\text { Jody Overland, Kenneth L. } \\
\text { Simons and Michael Spagat }\end{array}$ & Nov. 2000 \\
\hline No. 353 Disintegration and Trade & Jarko Fidrmuc and Jan Fidrmuc & Nov. 2000 \\
\hline $\begin{array}{l}\text { No. 352 Social Capital and Entrepreneurial Performance in Russia: A } \\
\text { Panel Study }\end{array}$ & Bat Batjargal & Dec. 2000 \\
\hline $\begin{array}{l}\text { No. 351 Entrepreneurial Versatility, Resources and Firm Performance in } \\
\text { Russia: A Panel Study }\end{array}$ & Bat Batjargal & Dec. 2000 \\
\hline
\end{tabular}




\begin{tabular}{|c|c|c|}
\hline $\begin{array}{l}\text { No. } 350 \text { The Dynamics of Entrepreneurial Networks in a Transitional } \\
\text { Economy: The Case of Russia }\end{array}$ & Bat Batjargal & Dec. 2000 \\
\hline $\begin{array}{l}\text { No. 349a R\&D and Technology Spillovers via FDI: Innovation and } \\
\text { Absorptive Capacity }\end{array}$ & Yuko Kinoshita & Apr. 2001 \\
\hline $\begin{array}{l}\text { No. } 349 \text { R\&D and Technology Spillovers via FDI: Innovation and } \\
\text { Absorptive Capacity }\end{array}$ & Yuko Kinoshita & Nov. 2000 \\
\hline $\begin{array}{l}\text { No. } 348 \text { Microeconomic aspects of Economic Growth in Eastern } \\
\text { Europe and the Former Soviet Union, 1950-2000 }\end{array}$ & Sergei Guriev and Barry W. Ickes & Nov. 2000 \\
\hline $\begin{array}{l}\text { No. } 347 \text { Effective versus Statutory Taxation: Measuring Effective Tax } \\
\text { Administration in Transition Economies }\end{array}$ & $\begin{array}{l}\text { Mark E. Schaffer and Gerard } \\
\text { Turley }\end{array}$ & Nov. 2000 \\
\hline $\begin{array}{l}\text { No. } 346 \text { Objectives and Constraints of Entrepreneurs: Evidence from } \\
\text { Small and Medium Size Enterprises in Russia and Bulgaria }\end{array}$ & $\begin{array}{l}\text { Francesca Pissarides, Miroslav } \\
\text { Singer and Jan Svejnar }\end{array}$ & Oct. 2000 \\
\hline No. 345 Corruption and Anticorruption in the Czech Republic & $\begin{array}{l}\text { Lubomír Lízal and Evžen } \\
\text { Kočenda }\end{array}$ & Oct. 2000 \\
\hline No. 344 The Effects of Direct Foreign Investment on Domestic Firms & Jozef Konings & Oct. 2000 \\
\hline No. 343 On the Identification of Relative Wage Rigidity Dynamics & Patrick A. Puhani & Oct. 2000 \\
\hline $\begin{array}{l}\text { No. } 342 \text { The Determinants of Foreign Direct Investment in Transition } \\
\text { Economies }\end{array}$ & Alan A. Bevan and Saul Estrin & Oct. 2000 \\
\hline No. 341 The Global Spread of Stock Exchanges, 1980-1998 & Klaus Weber and Gerald F. Davis & Nov. 2000 \\
\hline $\begin{array}{l}\text { No. } 340 \text { The Costs and Benefits of Euro-isation in Central-Eastern } \\
\text { Europe Before or Instead of EMU Membership }\end{array}$ & D. Mario Nuti & Oct. 2000 \\
\hline No. 339 Debt Overhang and Barter in Russia & $\begin{array}{l}\text { Sergei Guriev, Igor Makarov and } \\
\text { Mathilde Maurel }\end{array}$ & Sept. 2000 \\
\hline $\begin{array}{l}\text { No. } 338 \text { Firm Performance and the Political Economy of Corporate } \\
\text { Governance: Survey Evidence for Bulgaria, Hungary, Slovakia and } \\
\text { Slovenia }\end{array}$ & $\begin{array}{l}\text { Patrick Paul Walsh and Ciara } \\
\text { Whela }\end{array}$ & July 2000 \\
\hline No. 337 Investment and Instability & $\begin{array}{l}\text { Nauro F. Campos and Jeffrey B. } \\
\text { Nugent }\end{array}$ & May 2000 \\
\hline $\begin{array}{l}\text { No. } 336 \text { The Evolution of the Insurance Sector in Central and } \\
\text { Eastern Europe and the former Soviet Union }\end{array}$ & Robert B.K. Pye & Aug. 2000 \\
\hline $\begin{array}{l}\text { No. } 335 \text { Institutional Technology and the Chains of Trust: Capital } \\
\text { Markets and Privatization in Russia and the Czech Republic }\end{array}$ & Bruce Kogut and Andrew Spicer & Aug. 2000 \\
\hline No. 334 The Evolution of Market Integration in Russia & $\begin{array}{l}\text { Daniel Berkowitz and David N. } \\
\text { DeJong }\end{array}$ & Aug. 2000 \\
\hline No. 333 Efficiency and Market Share in Hungarian Corporate Sector & László Halpern and Gábor Körösi & July 2000 \\
\hline No. 332 Search-Money-and-Barter Models of Financial Stabilization & $\begin{array}{l}\text { S.I. Boyarchenko and S.Z. } \\
\text { Levendorskii }\end{array}$ & July 2000 \\
\hline $\begin{array}{l}\text { No. } 331 \text { Worker Training in a Restructuring Economy: Evidence from } \\
\text { the Russian Transition }\end{array}$ & $\begin{array}{l}\text { Mark C. Berger, John S. Earle } \\
\text { and Klara Z. Sabirianova }\end{array}$ & Aug. 2000 \\
\hline $\begin{array}{l}\text { No. } 330 \text { Economic Development in Palanpur 1957-1993: A Sort of } \\
\text { Growth }\end{array}$ & Peter Lanjouw & Aug. 2000 \\
\hline $\begin{array}{l}\text { No. } 329 \text { Trust, Organizational Controls, Knowledge Acquisition from } \\
\text { the Foreign Parents, and Performance in Vietnamese International Joint } \\
\text { Ventures }\end{array}$ & $\begin{array}{l}\text { Marjorie A. Lyles, Le Dang } \\
\text { Doanh, and Jeffrey Q. Barden }\end{array}$ & June 2000 \\
\hline $\begin{array}{l}\text { No. } 328 \text { Comparative Advertising in the Global Marketplace: The } \\
\text { Effects of Cultural Orientation on Communication }\end{array}$ & $\begin{array}{l}\text { Zeynep Gürhan-Canli and } \\
\text { Durairaj Maheswaran }\end{array}$ & Aug. 2000 \\
\hline No. 327 Post Privatization Enterprise Restructuring & Morris Bornstein & July 2000 \\
\hline No. 326 Who is Afraid of Political Instability? & $\begin{array}{l}\text { Nauro F. Campos and Jeffrey B. } \\
\text { Nugent }\end{array}$ & July 2000 \\
\hline No. 325 Business Groups, the Financial Market and Modernization & Raja Kali & June 2000 \\
\hline $\begin{array}{l}\text { No. } 324 \text { Restructuring with What Success? A Case Study of Russian } \\
\text { Firms }\end{array}$ & Susan Linz & July 2000 \\
\hline $\begin{array}{l}\text { No. } 323 \text { Priorities and Sequencing in Privatization: Theory and } \\
\text { Evidence from the Czech Republic }\end{array}$ & $\begin{array}{l}\text { Nandini Gupta, John C. Ham and } \\
\text { Jan Svejnar }\end{array}$ & May 2000 \\
\hline $\begin{array}{l}\text { No. } 322 \text { Liquidity, Volatility, and Equity Trading Costs Across } \\
\text { Countries and Over Time }\end{array}$ & $\begin{array}{l}\text { Ian Domowitz, Jack Glen and } \\
\text { Ananth Madhavan }\end{array}$ & Mar. 2000 \\
\hline
\end{tabular}




\begin{tabular}{|c|c|c|}
\hline $\begin{array}{l}\text { No. } 321 \text { Equilibrium Wage Arrears: A Theoretical and Empirical } \\
\text { Analysis of Institutional Lock-In }\end{array}$ & $\begin{array}{l}\text { John S. Earle and Klara Z. } \\
\text { Sabirianova }\end{array}$ & Oct. 2000 \\
\hline No. 320 Rethinking Marketing Programs for Emerging Markets & $\begin{array}{l}\text { Niraj Dawar and Amitava } \\
\text { Chattopadhyay }\end{array}$ & June 2000 \\
\hline $\begin{array}{l}\text { No. } 319 \text { Public Finance and Low Equilibria in Transition Economies: } \\
\text { the Role of Institutions }\end{array}$ & $\begin{array}{l}\text { Daniel Daianu and Radu } \\
\text { Vranceanu }\end{array}$ & June 2000 \\
\hline $\begin{array}{l}\text { No. } 318 \text { Some Econometric Evidence on the Effectiveness of Active } \\
\text { Labour Market Programmes in East Germany }\end{array}$ & $\begin{array}{l}\text { Martin Eichler and Michael } \\
\text { Lechner }\end{array}$ & June 2000 \\
\hline No. 317 A Model of Russia's "Virtual Economy" & R.E Ericson and B.W Ickes & May 2000 \\
\hline $\begin{array}{l}\text { No. } 316 \text { Financial Institutions, Financial Contagion, and Financial } \\
\text { Crises }\end{array}$ & $\begin{array}{l}\text { Haizhou Huang and Chenggang } \\
\mathrm{Xu}\end{array}$ & Mar. 2000 \\
\hline $\begin{array}{l}\text { No. } 315 \text { Privatization versus Regulation in Developing Economies: The } \\
\text { Case of West African Banks }\end{array}$ & $\begin{array}{l}\text { Jean Paul Azam, Bruno Biais, and } \\
\text { Magueye Dia }\end{array}$ & Feb. 2000 \\
\hline $\begin{array}{l}\text { No. } 314 \text { Is Life More Risky in the Open? Household Risk-Coping and } \\
\text { the Opening of China's Labor Markets }\end{array}$ & John Giles & Apr. 2000 \\
\hline $\begin{array}{l}\text { No. } 313 \text { Networks, Migration and Investment: Insiders and Outsiders in } \\
\text { Tirupur's Production Cluster }\end{array}$ & $\begin{array}{l}\text { Abhijit Banerjee and Kaivan } \\
\text { Munshi }\end{array}$ & Mar. 2000 \\
\hline $\begin{array}{l}\text { No. } 312 \text { Computational Analysis of the Impact on India of the Uruguay } \\
\text { Round and the Forthcoming WTO Trade Negotiations }\end{array}$ & $\begin{array}{l}\text { Rajesh Chadha, Drusilla K. } \\
\text { Brown, Alan V. Deardorff and } \\
\text { Robert M. Stern }\end{array}$ & Mar. 2000 \\
\hline No. 311 Subsidized Jobs for Unemployed Workers in Slovakia & Jan. C. van Ours & May 2000 \\
\hline No. 310 Determinants of Managerial Pay in the Czech Republic & $\begin{array}{l}\text { Tor Eriksson, Jaromir Gottvald } \\
\text { and Pavel Mrazek }\end{array}$ & May 2000 \\
\hline $\begin{array}{l}\text { No. } 309 \text { The Great Human Capital Reallocation: An Empirical Analysis } \\
\text { of Occupational Mobility in Transitional Russia }\end{array}$ & Klara Z. Sabirianova & Oct. 2000 \\
\hline No. 308 Economic Development, Legality, and the Transplant Effect & $\begin{array}{l}\text { Daniel Berkowitz, Katharina } \\
\text { Pistor, and Jean-Francois Richard }\end{array}$ & Feb. 2000 \\
\hline $\begin{array}{l}\text { No. } 307 \text { Community Participation, Teacher Effort, and Educational } \\
\text { Outcome: The Case of El Salvador's EDUCO Program }\end{array}$ & Yasuyuki Sawada & Nov. 1999 \\
\hline No. 306 Gender Wage Gap and Segregation in Late Transition & Stepan Jurajda & May 2000 \\
\hline $\begin{array}{l}\text { No. } 305 \text { The Gender Pay Gap in the Transition from Communism: } \\
\text { Some Empirical Evidence }\end{array}$ & Andrew Newell and Barry Reilly & May 2000 \\
\hline No. 304 Post-Unification Wage Growth in East Germany & Jennifer Hunt & Nov. 1998 \\
\hline $\begin{array}{l}\text { No. } 303 \text { How Does Privatization Affect Workers? The Case of the } \\
\text { Russian Mass Privatization Program }\end{array}$ & Elizabeth Brainerd & May 2000 \\
\hline $\begin{array}{l}\text { No. } 302 \text { Liability for Past Environmental Contamination and } \\
\text { Privatization }\end{array}$ & Dietrich Earnhart & Mar. 2000 \\
\hline No. 301 Varieties, Jobs and EU Enlargement & $\begin{array}{l}\text { Tito Boeri and Joaquim Oliveira } \\
\text { Martins }\end{array}$ & May 2000 \\
\hline No. 300 Employer Size Effects in Russia & Todd Idson & Apr. 2000 \\
\hline $\begin{array}{l}\text { No. } 299 \text { Information Complements, Substitutes, and Strategic Product } \\
\text { Design }\end{array}$ & $\begin{array}{l}\text { Geoffrey G. Parker and Marshall } \\
\text { W. Van Alstyne }\end{array}$ & Mar. 2000 \\
\hline $\begin{array}{l}\text { No. } 298 \text { Markets, Human Capital, and Inequality: Evidence from Rural } \\
\text { China }\end{array}$ & $\begin{array}{l}\text { Dwayne Benjamin, Loren Brandt, } \\
\text { Paul Glewwe, and Li Guo }\end{array}$ & May 2000 \\
\hline No. 297 Corporate Governance in the Asian Financial Crisis & $\begin{array}{l}\text { Simon Johnson, Peter Boone, } \\
\text { Alasdair Breach, and Eric } \\
\text { Friedman }\end{array}$ & Nov. 1999 \\
\hline No. 296 Competition and Firm Performance: Lessons from Russia & J. David Brown and John S. Earle & Mar. 2000 \\
\hline No. 295 Wage Determination in Russia: An Econometric Investigation & $\begin{array}{l}\text { Peter J. Luke and Mark E. } \\
\text { Schaffer }\end{array}$ & Mar. 2000 \\
\hline $\begin{array}{l}\text { No. } 294 \text { Can Banks Promote Enterprise Restructuring?: Evidence From } \\
\text { a Polish Bank's Experience }\end{array}$ & John P. Bonin and Bozena Leven & Mar. 2000 \\
\hline No. 293 Why do Governments Sell Privatised Companies Abroad? & $\begin{array}{l}\text { Bernardo Bortolotti, Marcella } \\
\text { Fantini and Carlo Scarpa }\end{array}$ & Mar. 2000 \\
\hline $\begin{array}{l}\text { No. } 292 \text { Going Public in Poland: Case-by-Case Privatizations, Mass } \\
\text { Privatization and Private Sector Initial Public Offerings }\end{array}$ & Wolfgang Aussenegg & Dec. 1999 \\
\hline
\end{tabular}




\begin{tabular}{|c|c|c|}
\hline $\begin{array}{l}\text { No. 291a Institutional Technology and the Chains of Trust: Capital } \\
\text { Markets and Privatization in Russia and the Czech Republic }\end{array}$ & Bruce Kogut and Andrew Spicer & Feb. 2001 \\
\hline $\begin{array}{l}\text { No. } 291 \text { Institutional Technology and the Chains of Trust: Capital } \\
\text { Markets and Privatization in Russia and the Czech Republic }\end{array}$ & Bruce Kogut and Andrew Spicer & Mar. 1999 \\
\hline No. 290 Banking Crises and Bank Rescues: The Effect of Reputation & Jenny Corbett and Janet Mitchell & Jan. 2000 \\
\hline $\begin{array}{l}\text { No. } 289 \text { Do Active Labor Market Policies Help Unemployed Workers to } \\
\text { Find and Keep Regular Jobs? }\end{array}$ & Jan C. van Ours & Feb. 2000 \\
\hline No. 288 Consumption Patterns of the New Elite in Zimbabwe & Russell Belk & Feb. 2000 \\
\hline $\begin{array}{l}\text { No. } 287 \text { Barter in Transition Economies: Competing Explanations } \\
\text { Confront Ukranian Data }\end{array}$ & $\begin{array}{l}\text { Dalia Marin, Daniel Kaufmann } \\
\text { and Bogdan Gorochowskij }\end{array}$ & Jan. 2000 \\
\hline $\begin{array}{l}\text { No. } 286 \text { The Quest for Pension Reform: Poland's Security through } \\
\text { Diversity }\end{array}$ & $\begin{array}{l}\text { Marek Góra and Michael } \\
\text { Rutkowski }\end{array}$ & Jan. 2000 \\
\hline No. 285 Disorganization and Financial Collapse & $\begin{array}{l}\text { Dalia Marin and Monika } \\
\text { Schnitzer }\end{array}$ & Oct. 1999 \\
\hline No. 284 Coordinating Changes in M-form and U-form Organizations & $\begin{array}{l}\text { Yingyi Qian, Gérard Roland and } \\
\text { Chenggang Xu }\end{array}$ & May 1999 \\
\hline $\begin{array}{l}\text { No. } 283 \text { Why Russian Workers Do Not Move: Attachment of Workers } \\
\text { Through In-Kind Payments }\end{array}$ & Guido Friebel and Sergei Guriev & Oct. 1999 \\
\hline No. 282 Lessons From Fiascos in Russian Corporate Governance & $\begin{array}{l}\text { Merritt B. Fox and Michael A. } \\
\text { Heller }\end{array}$ & Oct. 1999 \\
\hline $\begin{array}{l}\text { No. } 281 \text { Income Distribution and Price Controls: Targeting a Social } \\
\text { Safety Net During Economic Transition }\end{array}$ & $\begin{array}{l}\text { Michael Alexeev and James } \\
\text { Leitzel }\end{array}$ & Mar. 1999 \\
\hline $\begin{array}{l}\text { No. 280: Starting Positions, Reform Speed, and Economic Outcomes in } \\
\text { Transitioning Economies }\end{array}$ & William Hallagan and Zhang Jun & Jan. 2000 \\
\hline No. 279 : The Value of Prominent Directors & $\begin{array}{l}\text { Yoshiro Miwa \& J. Mark } \\
\text { Ramseyer }\end{array}$ & Oct. 1999 \\
\hline No. 278: The Syste & Kornai & Apr. 1998 \\
\hline $\begin{array}{l}\text { No. 277: The Developmental Consequences of Foreign Direct } \\
\text { Investment in the Transition from Socialism to Capitalism: The } \\
\text { Performance of Foreign Owned Firms in Hungary }\end{array}$ & Lawrence Peter King & Sept. 1999 \\
\hline $\begin{array}{l}\text { No. 276: Stability and Disorder: An Evolutionary Analysis of Russia's } \\
\text { Virtual Economy }\end{array}$ & $\begin{array}{l}\text { Clifford Gaddy and Barry W. } \\
\text { Ickes }\end{array}$ & Nov. 1999 \\
\hline $\begin{array}{l}\text { No. 275: Limiting Government Predation Through Anonymous } \\
\text { Banking: A Theory with Evidence from China. }\end{array}$ & $\begin{array}{l}\text { Chong-En Bai, David D. Li, } \\
\text { Yingyi Qian and Yijiang Wang }\end{array}$ & July 1999 \\
\hline No. 274: Transition with Labour Supply & Tito Boeri & Dec. 1999 \\
\hline $\begin{array}{l}\text { No. 273: Sectoral Restructuring and Labor Mobility: A Comparative } \\
\text { Look at the Czech Republic }\end{array}$ & Vit Sorm and Katherine Terrell & Nov. 1999 \\
\hline $\begin{array}{l}\text { No. 272: Published in: Journal of Comparative Economics "Returns to } \\
\text { Human Capital Under the Communist Wage Grid and During the } \\
\text { Transition to a Market Economy" Vol. 27, pp. 33-60 1999. }\end{array}$ & $\begin{array}{l}\text { Daniel Munich, Jan Svejnar and } \\
\text { Katherine Terrell }\end{array}$ & Oct. 1999 \\
\hline $\begin{array}{l}\text { No. 271: Barter in Russia: Liquidity Shortage Versus Lack of } \\
\text { Restructuring }\end{array}$ & $\begin{array}{l}\text { Sophie Brana and Mathilde } \\
\text { Maurel }\end{array}$ & June 1999 \\
\hline $\begin{array}{l}\text { No. 270: Tests for Efficient Financial Intermediation with Application to } \\
\text { China }\end{array}$ & Albert Park and Kaja Sehrt & Mar. 1999 \\
\hline $\begin{array}{l}\text { No. 269a: Russian Privatization and Corporate Governance: What Went } \\
\text { Wrong? }\end{array}$ & $\begin{array}{l}\text { Bernard Black, Reinier Kraakman } \\
\text { and Anna Tarassova }\end{array}$ & May 2000 \\
\hline $\begin{array}{l}\text { No. 269: Russian Privatization and Corporate Governance: What Went } \\
\text { Wrong? }\end{array}$ & $\begin{array}{l}\text { Bernard Black, Reinier Kraakman } \\
\text { and Anna Tarassova }\end{array}$ & Sept. 1999 \\
\hline No. 268: Are Russians Really Ready for Capitalism? & Susan Linz & Sept. 1999 \\
\hline No. 267: Do Stock Markets Promote Economic Growth? & $\begin{array}{l}\text { Randall K. Filer, Jan Hanousek } \\
\text { and Nauro Campos }\end{array}$ & Sept. 1999 \\
\hline $\begin{array}{l}\text { No. 266: Objectivity, Proximity and Adaptability in Corporate } \\
\text { Governance }\end{array}$ & $\begin{array}{l}\text { Arnoud W.A Boot and Jonathan } \\
\text { R. Macey }\end{array}$ & Sept. 1999 \\
\hline $\begin{array}{l}\text { No. 265: When the Future is not What it Used to Be: Lessons from the } \\
\text { Western European Experience to Forecasting Education and Training in } \\
\text { Transitional Economies }\end{array}$ & $\begin{array}{l}\text { Nauro F. Campos, Gerard } \\
\text { Hughes, Stepan Jurajda, and } \\
\text { Daniel Munich }\end{array}$ & Sept. 1999 \\
\hline
\end{tabular}

